Vol. 24, No. 1, pp. 4 21, 2021.

\title{
Nanoparticle-Dispersed Colloidal Electrolytes for Advanced Lithium Batteries
}

\author{
Minhong Lim*, Youngseong Jo*, Hongkyung Lee ${ }^{\dagger}$ \\ Department of Energy Science and Engineering, Daegu Gyeongbuk Institute of Science and Technology (DGIST) \\ Daegu 42988, Republic of Korea
}

\section{나노입자가 분산된 콜로이드형 전해질의 차세대 이차전지로의 응용}

\author{
임민홍, 조영성*, 이홍경 \\ 대구경북과학기술원 에너지공학전공
}

(Received February 23 2021; Revised March 17 2021; Accepted March 17 2021)

\begin{abstract}
s
The merits and uniqueness of nanotechnology have long attracted great interest and attention from energy storage/conversion-related fields, especially in rechargeable lithium ( $\mathrm{Li}$ ) batteries. For instance, nanosizing of active materials can reduce the Li diffusion paths, far enhancing the cell rate capability. Besides, nanoscale coating is beneficial to improve the stabilities of electrochemical materials. Despite such benefits, since nanosized active materials are facing the limitation of practical viability along with energy density and manufacturing process, new application strategies of nanotechnology in batteries have been proposed through the functionalization of inactive battery components. Among them, in this study, we present a new, hybrid type of the electrolyte containing the highly dispersed, nanosized functional particles, namely, nanoparticle-dispersed colloidal electrolytes (NDCEs). Throughout the article, fundamentals, microscale structures, and designing principles of NDCEs are comprehensively studied to achieve the desired properties for successful applications in conventional Li-ion batteries and beyond Li-ion systems, such as rechargeable Li-metal batteries. On a basis of the interesting features of NDCEs, future perspectives are suggested, which may help move forward its commercialization in the future battery technologies.
\end{abstract}

Keywords: Electrolytes, Functional nanoparticles, Lithium Batteries, Lithium Metal Battery, Nanoparticledispersed Colloidal Electrolytes

"Both authors contributes equally.

Corresponding Author: Hongkyung Lee

E-mail: hongkyung.lee@dgist.ac.kr

4|| 세라미스흐 


\section{1. 서론}

소재의 나노화 (10억분의 1)는 기존 마이크로 (100만 분의 1) 이상의 스케일에서 와는 달리 원자, 분자 자체 의 특성에 직접적인 영향을 받게 되고, 이에 따라 다양 한 특성의 변화를 가져올 수 있다. 입자가 나노화됨에 따라 흡착, 응집 그리고 촉매능과 같은 표면특성의 변 화, 강도, 경도 등의 기계적 특성의 변화, 강자성체의 상 자성화, 밴드 갭의 변화 등의 전자적 특성의 변화와 같 은 다양한 물리화학적 성질이 변화되고, ${ }^{1-4)}$ 특수한 기능 성이 부여된 나노 소재는 도입되는 양에 상관없이 에너 지, 환경, 생물, 의료, 기계 등 다양한 분야로 활용되고 있다. ${ }^{5-9)}$

그 중 에너지 분야에서 나노 소재는 이차전지 소재 부 분에서 많은 응용 연구가 진행되어왔는데, 특히 이차전 지의 에너지 밀도 향상, 고전압 구동, 산화/환원 안정성 등 이차전지의 성능 및 안전성을 확보하는데 있어 혁신 을 가져왔다. ${ }^{10-12)}$ 대표적인 예로, Goodenough 교수가 보고한 올리빈계 $\mathrm{LiFePO}_{4}$ 양극활물질은 우수한 가역성 및 안전성에도 불구하고 리튬이온의 확산경로가 제한되 고 전기전도도가 낮은 한계점 등이 상용화에 큰 걸림돌 이 되었으나, ${ }^{13)}$ 나노스케일의 활물질 합성을 통해 리튬 이온의 확산경로를 획기적으로 단축시켜 원활한 충방전 을 가능케하였다. ${ }^{14,15)}$ 또한 나노 수준의 표면 탄소코팅은 전기전도도를 증가시켜 높은 충전 속도에서도 이론용량 을 구현할 수 있었다. ${ }^{16)}$ 다른 예로 실리콘 $(\mathrm{Si})$ 음극소재 는 $4200 \mathrm{mAh} \mathrm{g}^{-1}$ 의 이론용량을 구현할 만큼 유망한 음 극소재로 고려되어왔지만 충 - 방전 과정 중 극심한 부 피 팽창에 따른 전극 및 계면의 퇴화로 인해 상용화의 한계가 있었다. 나노와이어 기반의 전극 소재 활용은 이 러한 부피변화를 효과적으로 억제하여 전극의 가역성을 극적으로 향상시킨 대표적 예 이다. ${ }^{17)}$ 이외에도 다양한 나노기술이 접목된 전극 제조는 기존의 한계점을 극복 할 수 있는 기술로서 각광을 받아왔다.

그러나 나노기반 전극활물질의 이차전지 분야로의 응 용은 상용화에 있어 여러 제약이 따른다. 앞서 언급한 나노기술의 장점 이면에 매우 넓어진 표면적으로 인해
서 전해질과 전극 사이에 필수적으로 발생하는 계면 반 응 면적이 증가하여 전해질 및 리튬이온의 소모를 야기 시켜 전지의 장기 구동 특성이 저하되는 부작용이 공존 한다. ${ }^{18)}$ 뿐만 아니라 전극을 제조하는 공정상 슬러리 제 조단계에서의 용매에 따른 분산성 한계, 높은 공정 비용 관점에서의 한계점이 문제가 되고 있으며 나노입자의 낮은 탭밀도로 인해서 전극의 후막화 및 고밀도화가 제 한되어 전지의 부피당 에너지 밀도가 현저히 낮아지는 등의 단점이 있어 중대형 이차전지 개발의 큰 주안점인 고에너지밀도 구현이 어렵다는 문제가 남아 있다.

그럼에도 불구하고 나노소재가 가지고 있는 다양한 장점을 활용하여 이차전지 분야로의 응용은 계속해서 시도되고 있다. 특히, 전기화학적으로 비활성한 소재 및 부품으로의 나노 기술 응용은 현 이차전지 및 차세대 전 지 개발 분야에서 그 활용가치가 주목받고 있다. 예를 들어, 이차전지 내 필수 부품소재인 폴리올레핀 기반 분 리막에 무기물 나노소재 코팅층을 도입하여 기계적 물 성을 확보하여 전지의 안전성을 향상시키는 연구가 대 표적이며, ${ }^{11,12,19,20)}$ 전극 복합체에 카본나노튜브를 도입하 여 전극 설계에서의 전도성 확보 및 전극 결착력 확보를 도모하는 전략 또한 제안되고 있다. ${ }^{21-23)}$ 최근 고전압에 서의 양극활물질 결정구조 안정성 및 계면 제어를 위한 무기물 나노소재를 코팅하는 연구 ${ }^{24,25)}$ 등이 활발히 진행 되어 현재 상용수준에서의 검증이 확보된 상태이다. 전 지의 안전성을 도모할 수 있는 고분자 전해질의 전도성, 기계적 안정성, 계면 안정성을 향상시키기 위한 무기물 나노입자의 첨가와, ${ }^{26,27)}$ 더 나아가 고에너지밀도를 구 현할 수 있는 차세대 리튬금속전지 내 유·무기 나노 코 팅 보호막을 통한 리튬금속 전극의 계면 안정성 확보 연 구 $^{28,29)}$ 등이 차세대 리튬이차전지 상용화를 위해 활발히 진행되어 왔다.

이외에도 최근 리튬이차전지의 성능 향상을 위해 새 로운 방식으로 나노기술 활용법이 보고되고 있다. 그 중 에서도 액체 전해질에 나노입자를 분산시킨 콜로이드 형태의 전해질은 전해질 종류에 크게 의존하는 이온 전 달 특성 및 계면 안정성 향상에 있어 새로운 패러다임을 제시하였다. 리튬이차전지에 사용되는 액체 전해질은 


\section{특 집 표 임민홍, 조영성, 이홍경}

(a)

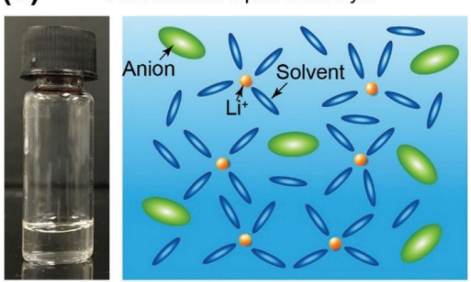

(c) (b) Nanoparticle-dispersed colloidal electrolyte

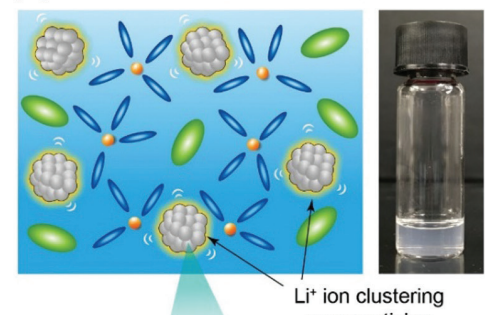

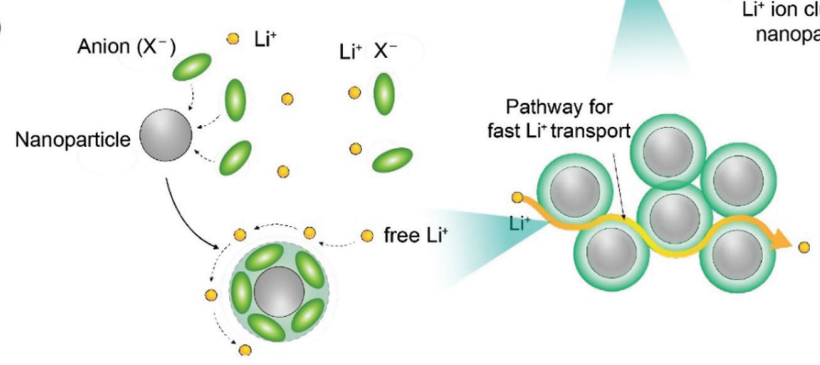

Fig. 1. 콜로이드 전해질(solid-in-liquid)의 용매화 구조 모식도. (a) 염과 용매로 구성된 상용화 전해질의 미세 구조, (b) 나노입자가 염-용 매간 미세 배위에 개입된 구조, (c) 나노입자 표면으로의 음이온 흡착 유도에 따른 자유 리튬이온 수 향상 및 새로운 이온 전달 경로 (Grotthuss 메커니즘) 확보 형태 제시

크게 염, 유기용매, 기타 첨가제 등으로 구성 되어있으 며, 전해질의 대부분을 차지하는 염/유기용매의 조합이 전해질 자체의 특성을 대부분 결정하게 된다. 하지만 전 해질의 염/유기용매 조합만으로 이온전달 특성과 계면 물성을 강화시키는 전략은 한계가 있고 전기화학적 반 응으로 형성되는 활물질과 전해질 사이의 계면 조성 및 물성은 예측, 제어하기가 매우 제한적이다. 예를 들어, 계면의 기계적 물성을 강화시키기 위해 무기물의 함량 이 증대되어야 하지만 염/용매 조성만으로 특정 물질의 함량을 증대시키는 것은 무리가 있다. 반면, 나노입자가 도입된 콜로이드형 전해질은 전극 계면반응에 참여하여 계면 내 무기물 함량을 증가 시킬 수 있는 가능성이 보 고됨에 따라 계면의 물성을 직접적으로 제어할 수 있는 독특한 장점이 확인되었다. 이에 따라 본 논문에서는 상 기 콜로이드형 전해질의 개념에 대해 소개하고 이를 구 현할 수 있는 기능성 나노소재들과 나노과학을 접목한 새로운 형태의 콜로이드형 전해질의 설계 및 응용 사례 를 다루며, 향후 개발 방향에 대해 논하고자 한다.

\section{2. 콜로이드형 전해질의 구조}

콜로이드형 전해질은 고상의 나노입자를 액상의 용매 에 분산시킨 형태이며, 일종의 유무기 하이브리드 형태 의 전해질로 간주된다. 하이브리드 형태의 전해질은 고 분자 전해질의 이온전도도를 향상시키기 위한 목적으 로 고분자의 결정성을 낮추고 리튬이온의 이동도를 높 일 수 있는 세라믹 나노입자가 도입된 세라믹/고분자 복 합 전해질 (Solid-in-polymer)이 일반적이나, ${ }^{30,31)}$ 본 논문에서 다루는 콜로이드형 전해질은 액체전해질 내에 나노입자를 분산시킨 형태 (Solid-in-liquid)로 기존의 세라믹/고분자 복합 전해질과는 다른 개념의 하이브리 드 전해질이다 (Fig. 1). 나노입자가 전해질 상에서 자유 롭게 움직일 수 있고, 리튬 양이온 및 음이온과의 상호 작용을 통해 리튬이온의 전달 경로를 제어하거나 계면 반응에 일부 참여할 수도 있어, 세라믹/고분자 복합 전 해질에서의 세라믹 나노입자의 역할과는 상이하다 (Fig. 1c). 일반적으로 전해질 내에서의 이온 전달 특성은 염 과 용매의 종류, 농도와 같은 조성에 의해서 지배되는 데, 나노입자는 염 - 용매간 미세 배위 구조에 개입할 수 있어 염의 해리도 및 이온 전달 경로를 독립적으로 변화 시켜 기존 전해질 설계 원리에서 벗어난 새로운 형태의 전해질 구조로 설계될 수 있다 (Fig. 1a, b). 또한 계면 


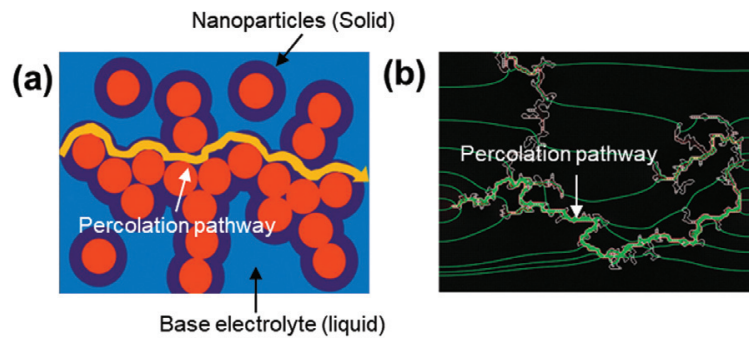

Fig. 2. (a) 나노입자의 연결에 따른 이온 전달 경로 모식도, (b) $2 \mathrm{D}$ Monte-Carlo 시뮬레이션을 통해 확인한 클러스터 형 성에 따른 전류 분포도. Reproduced from ref.32 with permission of Royal Society of Chemistry.

형성 반응 측면에서, 특정 전기화학 반응을 유도하여 전 극 계면 조성 및 구조의 개질을 목적으로 도입되는 용융 성 첨가제의 경우와 유사 하지만, 계면에서의 화학적/전 기화학적 반응경로를 예측하기 어려운 용융성 첨가제와 는 달리 나노소재는 공침을 통해 계면형성 반응에 직접 적으로 참여하여 물성강화를 효과적으로 유도할 수 있 다. 분산된 나노입자의 종류 및 형태, 크기, 표면 관능기 에 따라 전해질 내에서의 분산 특성 및 전기화학적 특성 이 매우 상이할 수 있어 염 - 용매-나노입자 간 미세 구 조에 대한 이해와 이를 통한 설계원리 확립이 중요하다.

\section{3. 콜로이드형 전해질 설계 주요인자}

콜로이드 상을 유지하기 위해서 나노입자의 분산성 확보가 우선시되어야 함을 감안할 때 단일 입자의 크기 가 작을수록, 표면적이 증가하여 전해질 내 이온종 들 과의 상호작용 기회가 증가하고 그 결과 침전 억제 효과 및 우수한 분산특성이 확보된다. 반면, 높은 함량의 나 노입자 도입은 분산성을 현저히 낮출 뿐만 아니라 전해 질의 점도를 높이기 때문에 오히려 리튬이온의 전도를 방해할 수 있어서 높은 비표면적을 갖는 나노입자를 소 량 도입하여 분산성을 오래도록 유지하는 것이 콜로이 드형 전해질 설계의 기본 조건이다.

나노입자의 분산 상태뿐만 아니라 나노입자 간 연 결성 또한 콜로이드형 전해질 설계의 주요 인자이 다. 일반적인 전해질의 경우, 전기장 하 이온의 이주 (electromigration)는 용매화 구조형태로 수송되는
Vehicle 메커니즘에 지배되는데 반해, Fig. 2에 도시된 바와 같이, 콜로이드형 전해질의 경우 입자 간 연결성 (percolation regime)이 확보되었을 때, 입자 표면을 따 라 이온이 전달되는 hopping (Grotthuss 메커니즘)을 통한 전달 방식이 추가될 수 있다 (Fig. $2 \mathrm{a}, \mathrm{b}){ }^{22)}$ 입자 표면의 산도 (acidity)에 따라 리튬 염의 음이온을 끌어 당김으로써 표면 음전하가 확보되어 공간 전하 (space charge)의 불균일성을 완화시킬 수 있을 뿐만 아니라 양이온과 음이온 간의 결합을 약화시켜 리튬의 이온전 도성을 향상시킬 수 있다. 이처럼 나노입자 표면제어 및 입자 간의 연결성 확보를 통해 기존 전해질에서와는 달리 용매화 형태 수송모드와 이온전도특성이 뛰어난 hopping 모드가 결합된 하이브리드형 이온전달모드를 구현할 수 있다.

\section{1. 나노입자 표면 관능기}

콜로이드형 전해질 내 나노입자는 양이온 및 음이온 과의 상호작용을 통해 분산성을 확보할 수 있으며, 염용매간 미세 배위에 적극적으로 개입하여 이온 전달특 성을 개선할 수 있다. 이러한 작용들은 나노입자 표면의 화학적인 상태에 크게 의존하게 된다.

나노입자 표면 관능기에 의한 용매와의 친화성 및 산 도 (acidity)는 콜로이드 전해질의 분산성 및 이온 전 도 경로의 연결성, 용매화 구조에 지대한 영향을 미친 다. Bhattacharyya 그룹의 연구에 따르면, 입자 표면 에 소수성 관능기(methyl-trimethoxysilane (MTMS), octyltrimethoxysilane (OTMS))를 가지는 실리카 $\left(\mathrm{SiO}_{2}\right)$ 나노입자는 관능기간의 반데르발스 결합을 통해 하이드록실기 $(\mathrm{OH})$ 와 음이온 간의 상호작용을 활성 시 켜주며, 이에 따라 이온전도도를 향상시킨다 (Fig. 3aii, $3 \mathrm{a}-\mathrm{iii})^{35)}$ 하지만 소수성 관능기의 분자량이 과도 하게 클 경우 입체효과 (steric effect)로 인해 이온전 도 특성을 저해할 수 있기 때문에 적절한 관능기 선택 이 중요하다. 반면에 $\mathrm{OH}$ 관능기만을 가진 실리카의 경 우 입자 간의 강한 수소결합을 형성하게 되면 관능기 비 활성화로 인해 낮은 이온전도도를 갖게 되는 단점을 가 진다 (Fig. $3 \mathrm{a}-\mathrm{i})$. 또 다른 경우로 (3-aminopropyl) 
(a) (i) $\mathrm{OH}$

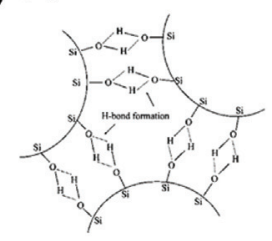

(iii) OTMS

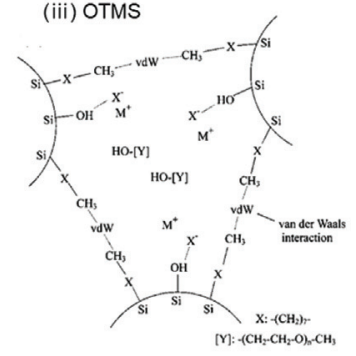

(b)

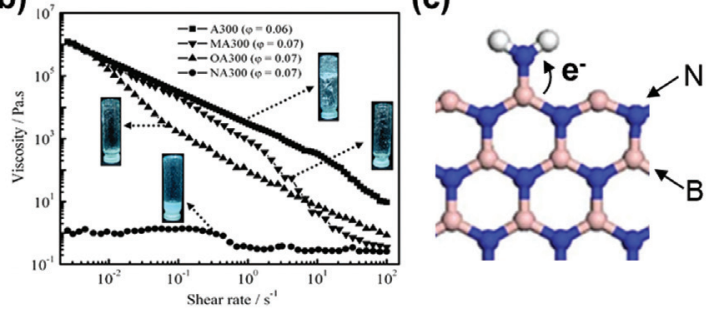

Fig. 3. (a) OH, MTMS, OTMS, APTMS 관능기를 가지는 실리카 나 노입자 간의 연결성 및 이온과의 결합 특성에 대한 모식도. (b) OH (A300), MTMS (MA300), OTMS (OA300), APTMS (NA300)에 따른 점도 및 물성. (c) $\mathrm{NH}_{2}$ 도입에 따른 Lewis acidity 향상 모식도. Reproduced from ref.35 with permission of ACS Publication.

trimethoxysilane (APTMS)를 가지는 실리카는 입 자 간의 응집보다 용매와의 상호작용이 우세하기 때문 에 낮은 점도를 구현할 수 있지만, 리튬이온과의 강한 정전기적 인력으로 인한 이온전도 저해 특성을 보인다 (Fig. 3a-iv). 이처럼 나노입자 표면 화학상태에 따라 응집도가 변화되어 입자 간 연결성 임계점 (percolation threshold)이 달라진다. 즉, 관능기는 용매화 구조의 변 형 및 콜로이드형 전해질의 물리적 특성 (강도, 점도) 을 제어하는 중요한 변수이다 (Fig. 3b). 우한대 Huang 그룹은 Boron Nitride Nanosheets (BNNS)를 분산시 킨 콜로이드형 전해질의 경우, ${ }^{33,34)}$ 붕소와 리튬 염 음 이온(TFSI ${ }^{-}$) 사이의 정전기적 인력을 통해 자유 리튬이 온 (free $\mathrm{Li}^{+}$)의 양이 증가함을 보고한 바 있다. 추가적 으로 표면에 아민기 $\left(\mathrm{NH}_{2}\right)$ 를 도입함으로써 붕소 자체
의 Lewis Acidity를 높여 정전기적 인력을 증진시켰다 (Fig. 3c).

이처럼 관능기 종류에 따라 관능기 자체가 전해질 구 성 성분과의 상호작용을 유도하거나, 나노입자 모체와 의 상호작용을 유도하는데에 중요한 역할을 하고, 콜로 이드형 전해질의 기계적 강도 및 이온전도도 등과 같은 전기화학적 특성과 매우 밀접한 관계를 가지기 때문에 최적의 관능기를 설정 및 도입하는 것이 콜로이드형 전 해질 설계에 있어서 매우 중요하다.

\section{2. 리튬 염의 종류}

나노입자와 음이온간의 상호작용력을 이용하여 리튬 이온의 이온전도도를 효과적으로 향상시키기 위해서는 적합한 염을 선정하는 것이 중요하다. 나노입자 도입에 따른 전해질 내 용매화 구조개입 및 이온전도도 향상 원 리에 대해서 명확히 규명된 바는 아직 없으나, 이전 연 구 결과에 따르면 전해질을 구성하는 성분 중 주로 음이 온과의 상호작용을 통해서 이온 전도 특성이 개선될 수 있다고 밝혔다. 독일 Max Planck 연구소의 J. Maier 박사 그룹은 서로 다른 음이온 반경을 가지는 $\mathrm{LiClO}_{4}$ 와 $\mathrm{LiBOB}$ 기반의 콜로이드형 전해질 비교 연구를 통해 음이온의 크기가 작을수록 나노입자에 따른 이온전도 도 향상이 유도될 수 있음을 실험적으로 규명했다 (Fig. $4 \mathrm{a}, \mathrm{b}){ }^{36)} \mathrm{LiClO}_{4}$ 와 $\mathrm{LiBOB}$ 염이 사용된 보레이트 계열 용매 기반 전해질의 이온전도도를 비교한 결과, $\mathrm{LiBOB}$ 염을 사용한 전해질의 이온전도도가 더 높았던 것과 달 리 $\left(\mathrm{LiClO}_{4}: \sim 1.0 \times 10^{-3} \mathrm{~S} \mathrm{~cm}^{-1}\right.$, LiBOB: $\sim 1.0 \times 10^{-2.7}$ $\mathrm{S} \mathrm{cm}^{-1}, 50{ }^{\circ} \mathrm{C}$ ) 실리카가 첨가된 콜로이드형 전해질 상 에서는 $\mathrm{LiClO}_{4}$ 염을 사용한 경우가 더 높은 수치를 나타 내었다. 이처럼 염의 음이온의 이온반경이 작을수록 나 노입자와 음이온간의 결합이 더욱 용이하기 때문에 기 존 이차전지 전해질에 주로 사용되고 있는 $\mathrm{PF}_{6}, \mathrm{BF}_{4}$ 와 같은 소형 음이온과의 조합을 통해서 극대화된 성능 향 상을 유도할 수 있을 것으로 기대된다. ${ }^{36)}$

콜로이드형 전해질에서 음이온과 나노입자 간의 결 합력 강화는 리튬 염의 해리도를 향상시켜 이온전도도 를 향상시킬 수 있기 때문에 염의 해리도가 낮은 전해질 

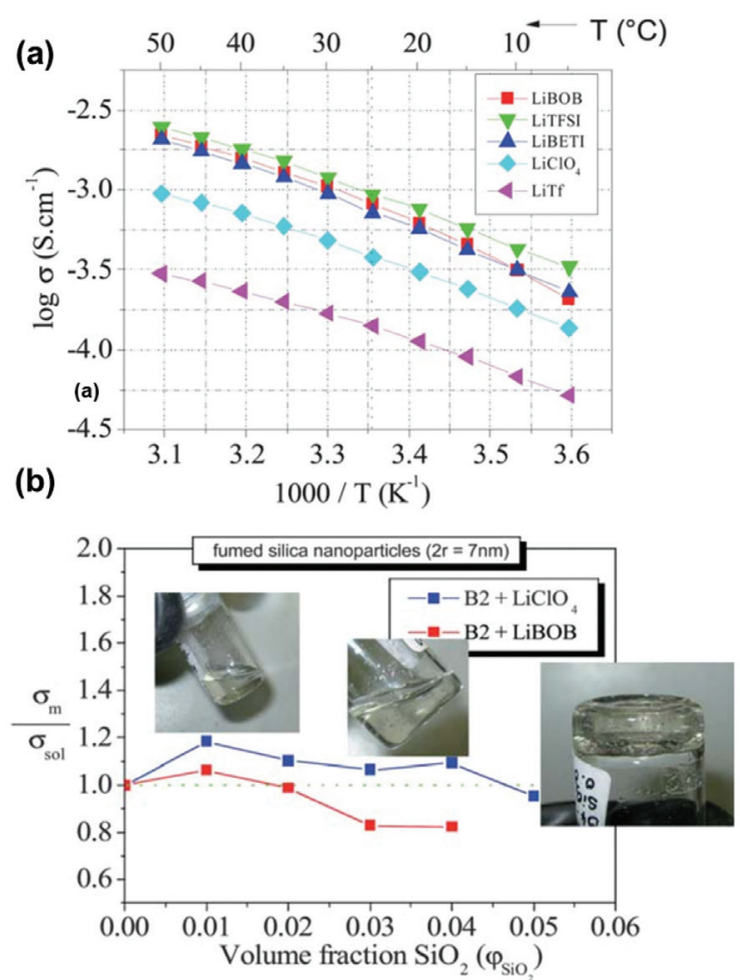

Fig. 4. (a) 서로 다른 음이온 크기를 가지는 염들의 이온전도도 비 교 도표 (b) $\mathrm{LiClO}_{4}$ 와 $\mathrm{LiBOB}$ 를 염으로 하는 전해질의 실리 카 농도에 따른 이온전도도 비교. Reproduced from ref.36 with permission of Royal Society of Chemistry.

에서 표면 산도가 높은 나노입자의 도입은 염 해리에 큰 기여를 할 수 있을 것으로 기대된다. 실제로 J. Maier 그룹은 유전 상수가 낮은 Tetrahydrofuran (THF)와 Polyethylene glycol (PEG)를 용매로 사용하고 $\mathrm{LiClO}_{4}$ 를 염으로 사용함으로써 염의 해리도가 낮은 전해질에 서 나노입자 $\left(7 \mathrm{~nm}-\mathrm{SiO}_{2}\right)$ 의 첨가에 따른 이온전도도 상 승을 확인하였다. 이외에도 많은 종류의 나노입자와 염/ 용매 조합에서의 나노 콜로이드형 전해질의 사례를 표 1 에 정리하였다. 전해질의 상대적으로 높은 염 해리도를 갖는 전해질의 경우 상대적으로 고함량의 나노입자 첨 가를 통해서 개선이 가능함을 확인했다. 한편, 나노입자 의 첨가량이 높을 경우 이온 전달을 물리적으로 방해할 수 있으므로 최적의 나노입자 첨가량을 기반으로 염과 용매의 적합성이 목적에 맞게 고려되어야 한다.

\section{4. 콜로이드형 전해질의 전기화학적 특성}

\section{1. 이온전도도 향상}

본 논문에서 언급하는 콜로이드형 전해질은 Soggysand 전해질로 활발히 연구가 된 바 있다. 표 1에 도시 된 바와 같이 실리카 나노입자를 도입한 연구 사례가 다 수 있는데, J. Maier 그룹은 전해질 조성 $1 \mathrm{M} \mathrm{LiClO}_{4}$ / $\mathrm{PEG}\left(\mathrm{Mw}=150 \mathrm{~g} \mathrm{~mol}^{-1}, \mathrm{PEG}-150\right)$ 에 실리카의 부피 분율 (volume fraction, $\varphi$ ) $\leq 0.03$ 를 첨가하여 콜로 이드형 전해질을 제작 및 실리카 나노입자 농도에 따라 최대 3.3배 이상의 이온전도도 향상을 확인하였다. 실 리카 표면 $\mathrm{OH}$ 작용기와 음이온의 정전기적 상호작용 을 유도함으로써 음이온과 리튬이온의 결합력을 약화 시켜 이온전도도를 향상시켰다. 허나, 나노입자의 응집 (agglomeration) 및 침전 (sedimentation) 현상으로 인한 네트워크의 불안정성으로 시간에 따른 전도도 감 소가 관측되는 문제가 확인됨에 따라 실리카 나노입자 의 반경, 농도 $(\varphi)$, 염의 농도 등 안정적인 네트워크 유 지를 위한 추가적인 연구의 필요성이 제기되었다. ${ }^{37}$

나노입자 간의 응집이 발생할 경우 네트워크의 붕괴 와 함께 물리적으로 이온의 움직임을 방해함으로써 이 온전도도 감소를 초래할 수 있는 반면에, 오히려 입자간 응집에 의해 형성된 percolation pathway를 통해 이온 전도 특성이 향상될 수도 있다. 실리카 표면 $\mathrm{OH}$ 관능기 는 음이온과의 상호작용을 통해 분산성 유지에 도움을 주고 이온전도도 향상에도 효과적이다. 허나, 입자 간 의 강력한 수소결합은 과도한 응집을 초래하고, 클러스 터 크기 증가함에 따라서 음이온과 결합할 수 있는 면 적 (관능기)이 감소되며, 물리적으로 이온수송을 방해 할 수 있다. Bhattacharyya는 실리카 표면의 친수성을 조절함으로써 수소결합에 의한 과도한 응집을 해소하 였는데, $\mathrm{OH}$ 관능기를 갖는 실리카에 소수성 관능기를 부분적으로 추가 도입하여 입자 간의 반데르발스 힘을 이용해 음이온과 상호작용할 수 있는 $\mathrm{OH}$ 관능기의 수 를 증가시켰다 (Fig. $5 \mathrm{a}$ ). 오히려 강한 친수성 관능기인 (3-aminopropyl)trimethoxy-silane (ATMS)의 경우, 유기용매와의 상호작용력이 증가하여 이온-쌍극자 결 
Table 1. 콜로이드형 전해질에 사용된 바탕 전해질, 나노입자 및 그에 따른 조건들

\begin{tabular}{|c|c|c|c|c|}
\hline 바탕 전해질 & 나노입자 & 나노입자의 농도 & 최종 콜로이드형 전해질 & 참고문헌 \\
\hline $\mathrm{LiClO}_{4}$ in $\mathrm{PEG}-150$ & $\mathrm{SiO}_{2}, 7$ and $10 \mathrm{~nm}$ & $\begin{array}{c}\varphi \leq 0.03 \\
\text { (volume fraction) }\end{array}$ & $1 \mathrm{M} \mathrm{LiClO}_{4}$ in $\mathrm{PEG}-150+\mathrm{SiO}_{2}$ & 37) \\
\hline $\begin{array}{c}\mathrm{LiPF}_{6} \text { in } \mathrm{EC} / \mathrm{DMC} \\
(1 / 1, \mathrm{w} / \mathrm{w})\end{array}$ & $\mathrm{SiO}_{2}, 7$ and $290 \mathrm{~nm}$ & $\begin{array}{c}\varphi \leq 0.08 \\
\text { (volume fraction) }\end{array}$ & $1 \mathrm{M} \mathrm{LiPF}_{6}$ in $\mathrm{EC} / \mathrm{DMC}(1 / 1, \mathrm{w} / \mathrm{w})+\mathrm{SiO}_{2}$ & 39) \\
\hline $\mathrm{LiClO}_{4}$ in $\mathrm{m}-\mathrm{PEG}$ & $\begin{array}{c}\mathrm{SiO}_{2}, 7 \mathrm{~nm} \\
\text { Methyl-capped } \mathrm{SiO}_{2} \\
\text { Amine-capped } \mathrm{SIO}_{2} \\
\text { Octyl-capped } \mathrm{SiO}_{2}\end{array}$ & $\begin{array}{c}\varphi \leq 0.07 \\
\text { (volume fraction) }\end{array}$ & $0.1 \mathrm{M} \mathrm{LiClO}_{4}$ in $\mathrm{m}-\mathrm{PEG}+\mathrm{SiO}_{2}$ & $35)$ \\
\hline $\begin{array}{l}\mathrm{LiBF}_{4} \text { in } \mathrm{EC} / \mathrm{PC}(1 / 1 \\
\mathrm{w} / \mathrm{w})\end{array}$ & $\begin{array}{l}\mathrm{Al}_{2} \mathrm{O}_{3} 24 \mathrm{~nm} \\
\mathrm{BaTiO}_{3}, 1 \mu \mathrm{m}\end{array}$ & $\begin{array}{l}5 \mathrm{wt} \% \text { and } 10 \mathrm{wt} \% \\
\text { (weight fraction) }\end{array}$ & $1 \mathrm{M} \mathrm{LiBF}_{4}$ in $\mathrm{EC} / \mathrm{PC}(1 / 1, \mathrm{w} / \mathrm{w})$ & 62) \\
\hline $\begin{array}{l}\mathrm{LiClO}_{4} \text { and } \mathrm{LiBOB} \\
\text { in borate ester (BE) }\end{array}$ & $\mathrm{SiO}_{2}, 7$ and $10 \mathrm{~nm}$ & $\begin{array}{c}\varphi \leq 0.15 \\
\text { (volume fraction) }\end{array}$ & $\begin{array}{l}\mathrm{LiClO}_{4} \text { in } \mathrm{BE}+\mathrm{SiO}_{2} \\
\mathrm{LiBOB} \text { in } \mathrm{BE}+\mathrm{SiO}_{2}\end{array}$ & 36) \\
\hline $\mathrm{LiClO}_{4}$ in THF & $\mathrm{SiO}_{2}, 100 \mathrm{~nm}$ & $\begin{array}{c}\varphi \leq 0.015 \\
\text { (volume fraction) }\end{array}$ & $0.1 \mathrm{M} \mathrm{LiClO}_{4}+\mathrm{THF}+\mathrm{SiO}_{2}$ & $63)$ \\
\hline $\begin{array}{l}\mathrm{LiClO}_{4} \text { in Methanol } \\
(\mathrm{MeOH})\end{array}$ & $\begin{array}{c}\mathrm{SiO}_{2}, 300 \mathrm{~nm} \\
\mathrm{TiO}_{2}, 300 \mathrm{~nm} \\
\mathrm{Al}_{2} \mathrm{O}_{3}, 300 \mathrm{~nm}\end{array}$ & $\begin{array}{c}\varphi \leq 0.7 \\
\text { (volume fraction) }\end{array}$ & $\begin{array}{c}0.1 \mathrm{M} \mathrm{LiClO}_{4} \text { in } \mathrm{MeOH}+\mathrm{SiO}_{2} \\
0.1 \mathrm{M} \mathrm{LiClO}_{4} \text { in } \mathrm{MeOH}+\mathrm{TiO}_{2} \\
0.1 \mathrm{M} \mathrm{LiClO}_{4} \text { in } \mathrm{MeOH}+\mathrm{Al}_{2} \mathrm{O}_{3} \\
0.1 \mathrm{M} \mathrm{LiClO}_{4} \text { in } \mathrm{DMSO}+\mathrm{SiO}_{2} \\
0.1 \mathrm{M} \mathrm{LiClO}_{4} \text { in THF }+\mathrm{SiO}_{2}\end{array}$ & 64) \\
\hline $\begin{array}{l}\text { LiTFSI + DOL/DME } \\
(1 / 1, \mathrm{v} / \mathrm{v})+\mathrm{LiNO}_{3}\end{array}$ & $\begin{array}{l}\text { BNNS, } 4.5 \mathrm{~nm} \text { (Thickness) } \\
\text { and } 1-3 \mu \mathrm{m} \text { (Lateral) }\end{array}$ & $\leq 10 \mathrm{mg} \mathrm{mL}^{-1}$ & $\begin{array}{l}1 \text { M LiTFSI in DOL/DME (1/1, v/v) + } 2 \text { wt\% } \\
\mathrm{LiNO}_{3}+\text { BNNS }\end{array}$ & 33) \\
\hline IL-NIMs & $\mathrm{ZrO}_{2}, 86 \mathrm{~nm}$ & - & $\mathrm{ZrO}_{2}-\mathrm{IL}-\mathrm{NIMs}$ & 48) \\
\hline $\begin{array}{c}\text { TEGDME } \\
\text { (Tetraethylene gly- } \\
\text { col dimethyl ether) }\end{array}$ & $\begin{array}{l}\mathrm{SiO}_{2}-\mathrm{SO}_{3} \mathrm{BF}_{3} \mathrm{Li} \\
\mathrm{SiO}_{2}-\mathrm{SO}_{3} \mathrm{Li}, 7 \mathrm{~nm}\end{array}$ & - & $\begin{array}{l}\mathrm{SiO}_{2}-\mathrm{SO}_{3} \mathrm{BF}_{3} \mathrm{Li} \text { in TEGDME } \\
\mathrm{SiO}_{2}-\mathrm{SO}_{3} \mathrm{Li} \text { in TEGDME }\end{array}$ & 47) \\
\hline $\begin{array}{c}\text { LiTFIS in PC + } 1 \\
\text { wt } \% \mathrm{LiNO}_{3}+2 \text { vol\% } \\
\text { VC }\end{array}$ & $\mathrm{SiO}_{2}, 10$ and $25 \mathrm{~nm}$ & - & $\begin{array}{c}1 \mathrm{M} \text { LiTFIS in } \mathrm{PC}+1 \mathrm{wt} \% \mathrm{LiNO}_{3}+2 \text { vol\% } \\
\mathrm{VC}+\mathrm{SiO}_{2}-\mathrm{PEGDME}\end{array}$ & 43) \\
\hline $\begin{array}{l}\text { LiTFSI in PC in MA } \\
\text { (methyl acetate) }\end{array}$ & PMMA, $260 \mathrm{~nm}$ & $11 \mathrm{wt} \%$ & LiTFSI in PC/MA $(3 / 2, v / v)$ & 49) \\
\hline $\begin{array}{c}\mathrm{LiPF}_{6} \text { in } \mathrm{EC} / \mathrm{EMC}+ \\
\mathrm{VC}\end{array}$ & $\mathrm{SiO}_{2}, 7 \mathrm{~nm}$ & $\leq 20 \mathrm{mg} \mathrm{mL}^{-1}$ & $\begin{array}{c}1 \mathrm{M} \mathrm{LiPF}_{6} \text { in } \mathrm{EC} / \mathrm{EMC}(3 / 7, \mathrm{w} / \mathrm{w})+2 \mathrm{wt} \% \\
\mathrm{VC}+\mathrm{SiO}_{2}\end{array}$ & 46) \\
\hline $\mathrm{LiPF}_{6}$ in EC/DEC & Nano diamond, $5 \mathrm{~nm}$ & $\leq 8.2 \mathrm{mg} \mathrm{mL}^{-1}$ & $1 \mathrm{M} \mathrm{LiPF}_{6}$ in $\mathrm{EC} / \mathrm{DEC}+\mathrm{SiO}_{2}$ & $57)$ \\
\hline $\mathrm{LiPF}_{6}$ in $\mathrm{EC} / \mathrm{DEC}$ & $\mathrm{MOF}, \sim 500 \mathrm{~nm}$ & $\leq 250 \mathrm{mg} \mathrm{mL}^{-1}$ & $1 \mathrm{M} \mathrm{LiPF}_{6}$ in $\mathrm{EC} / \mathrm{DEC}+\mathrm{MOF}$ & 40) \\
\hline
\end{tabular}

합에 의해 양이온을 끌여당겨 이온전도도가 감소될 수 도 있다. 정리하자면, 나노입자의 분산성은 이온전도도 확보에 중요한 변수이며 입자 표면특성에 의해 크게 지 배될 수 있고, 과도한 응집에 의한 침전 현상을 억제할 수 있다면 향상된 이온전도도를 얻을 수 있다. ${ }^{37,38)}$

콜로이드형 전해질 상에서의 이온전도도의 향상은 바탕 전해질 용매의 유전 상수와 매우 깊은 관련이 있 다. 예를 들어, $7 \mathrm{~nm}$ 실리카가 분산된 $1 \mathrm{M} \mathrm{LiPF}_{6}$ in Ethylene Carbonate (EC)/Dimethyl Carbonate
(DMC) $(1 / 1, \mathrm{w} / \mathrm{w})$ 와 $1 \mathrm{M} \mathrm{LiPF}_{6}$ in $\mathrm{DMC}$ 전해질을 사 용한 Bhattacharyya 연구팀에 의하면 EC 용매의 유무 에 따라 서로 다른 최대 이온전도도 수치를 가짐을 확인 할 수 있다. ${ }^{39)}$

이때, $\mathrm{EC}$ 용매의 유무는 전해질의 유전 상수의 차이 로 구분되는데, 높은 유전 상수를 나타내는 전해질의 경 우에는 실리카를 도입에 따른 이온전도도 상승폭이 2 배 인 반면, 낮은 유전 상수를 가지는 전해질은 이온전도도 가 최대 2.6 배 상승하였다. 이를 통해 유전 상수가 낮은 
(a)

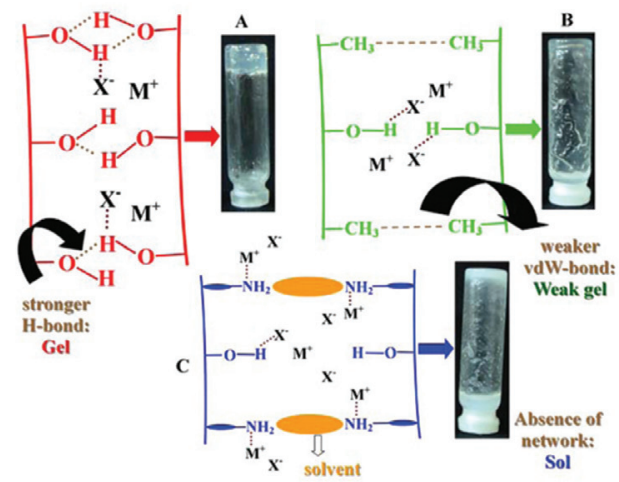

(b)

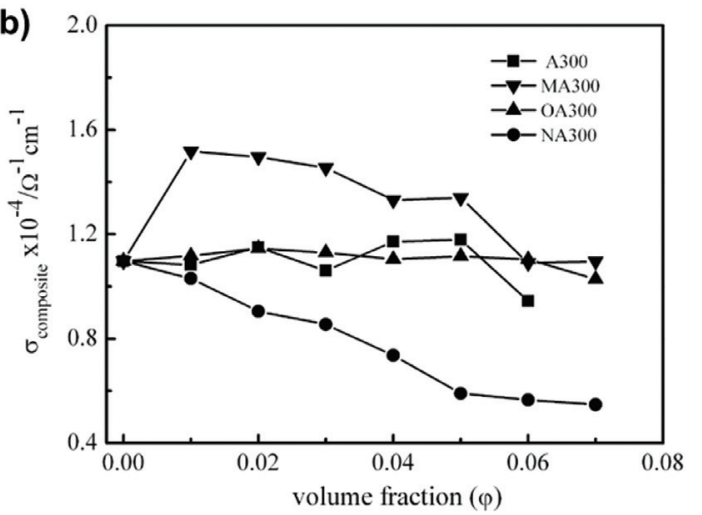

Fig. 5. (a) 실리카에 부여된 관능기 (친수성, 소수성, 용매 친화 성 친수성)별 전해질 내 분산 형태 및 결합 이온의 설명도. Reproduced from ref.38 with permission of ACS Publication. (b) 친수성 바탕 실리카(A300), 소수성 관능기가 달 리 실리카 (MA300, OA300) 및 용매와의 친화성을 띄는 친 수성 실리카 (NA300)의 분산 농도에 따른 이온전도도 변화. Reproduced from ref.35 with permission of ACS Publication.

전해질의 경우 실리카 첨가에 따른 효과가 극대화되는 것을 알 수 있는데, 이는 실리카를 통한 염의 해리가 유 전 상수가 더 낮을수록 극대화되기 때문으로 해석될 수 있다.

콜로이드형 전해질의 독특한 이온전도모드를 고려할 때, 저온 $\left(\leq 25{ }^{\circ} \mathrm{C}\right)$ 에서의 이온전도도 향상에 효과적 일 수 있다 (Fig. 6). J. Maier는 상용 카보네이트계 전 해질 $\left(1 \mathrm{M} \mathrm{LiPF}_{6}\right.$ in $\left.\mathrm{EC} / \mathrm{DMC}\right)$ 기반의 나노 실리카 (7 $\left.\mathrm{nm} \mathrm{SiO}_{2}\right)$ 기반의 콜로이드형 전해질을 제조한 후 $(\varphi \leq$ 0.08), 온도에 따른 이온전도도를 측정하였다. 상대적으 로 낮은 온도 $\left(\leq 25{ }^{\circ} \mathrm{C}\right)$ 에서 실리카 부피분율이 0.03 일 경우 가장 높은 이온전도도 $\left(\sim 1.5 \times 10^{-2} \mathrm{~S} \mathrm{~cm}^{-1}\right)$ 를 구
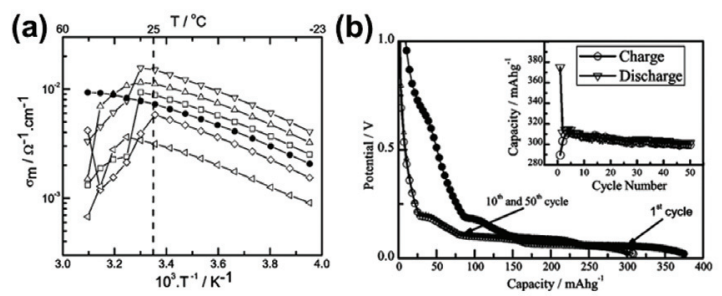

Fig. 6. (a) $7 \mathrm{~nm} \mathrm{SiO}$ 가 분산된 $1 \mathrm{M} \mathrm{LiPF}_{6}$ in $\mathrm{EC} / \mathrm{DMC}$ 전해질의 온도에 따른 이온전도도 및 (b) Graphite 음극 용량 구현 및 용량 유지율 특성. Reproduced from ref.39 with permission of IOP Publishing.

현하였고, $0.04,0.02$ 순으로 높은 수치를 보였으며 이 는 실리카를 포함하지 않는 바탕 전해질 $\left(\sim 7.0 \times 10^{-3} \mathrm{~S}\right.$ $\left.\mathrm{cm}^{-1}\right)$ 보다 향상된 수치이다. 이처럼 나노입자는 기존의 바탕 전해질이 가지는 저온 구동에서의 이온 전달 현상 한계를 극복함으로써 우수한 이온전도도를 확보 및 전 지 성능 향상을 유도할 수 있다. ${ }^{39}$

\subsection{Transference number $\left(\mathrm{t}_{\mathrm{Li}+}\right)$ 향상}

이온전도도 향상은 전지 구동 과정에서 발생하는 공 간 전하 (space charge) 및 리튬이온 플럭스의 균일성 을 강화하므로써 전해질 내부의 과전압 감소 및 용량유 지율 향상에 유리하다. 하지만 전지의 성능 확보를 위해 서는 이온전도도 뿐만 아니라 리튬이온 선택적 이동 역 시 매우 중요한 지표이다.

실리카를 포함하는 대부분의 나노입자는 콜로이드형 전해질에서 높은 부피분율 (농도)로 존재할 경우 이온의 이동을 물리적으로 방해하는데 이를 통한 이온전도도 감소폭이 음이온 고정으로 인한 이온전도도 상승폭보 다 높을 경우, 결론적으로 성능 저하를 초래한다. 그러 나 이온전도도가 감소하여도 오히려 리튬이온의 선택적 이동수 (transference number, $\mathrm{t}_{\mathrm{Li}+}$ ) 향상을 통해서 실 질적인 리튬이온 전달특성은 향상될 수 있다. 아래 식을 통해 확인된 바와 같이 양이온의 이동수는 양, 음이온을 포함한 전체 전하운반체 (charge carriers)의 mobility 대비 양이온의 상대적인 mobility $\left(u_{(L i)+}\right)$ 를 의미한다.

$$
t_{L i^{+}}=\frac{u_{L i^{+}}}{u_{L i^{+}}+u_{X^{-}}}
$$

이에 대한 한 예로, Y. $\mathrm{Lu}$ 그룹은 상용 전해질 $1 \mathrm{M}$ 


\section{특 집 표 임민홍, 조영성, 이홍경}

$\mathrm{LiPF}_{6}$ in $\mathrm{EC} /$ Diethyl Carbonate (DEC)에 다공성의 금속-유기구조체 (metal-organic framework, MOF) 입자를 125 및 $250 \mathrm{mg} \mathrm{mL}^{-1}$ 농도로 분산시켜 콜로이 드형 전해질을 제작하여 전지성능을 향상시켰다. ${ }^{40)}$ 바 탕 전해질 대비 $\mathrm{MOF}$ 분산 콜로이드형 전해질의 이온 전도도는 각 농도에서 오히려 $25 \%, 60 \%$ 감소한 반면, transference number는 최대 2 배 향상된 $0.57,0.61$ 을 가지며 이를 통해 전지 성능이 향상되었음을 보고하 였다. (바탕 전해질에서의 $t_{L i}{ }^{+}=0.3$ ). 실질적인 $\mathrm{Li}^{+}$이 온전도도 $\left(\sigma_{L i}\right)$ 는 측정된 이온전도도에서 $t_{L i}+$ 를 곱한 값임을 감안할 때, $\mathrm{Li}^{+}$이온 자체의 수송특성은 오히려 높아질 수 있고, 측정된 이온전도도에서의 감소를 높은 $t_{L i}$ 구현을 통해 극복할 수 있음을 의미한다. 뿐만 아니 라, 리튬이온 이동수 $t_{L i}+$ 를 향상시키는 것은 차세대 리 튬금속전지의 문제로 여겨지는 덴드라이트 성장 억제에 매우 중요한 변수로도 작용하기 때문에, 콜로이드형 전 해질을 설계하는데에 있어서 중요한 물성치이다.

이 밖에도 기능성 나노입자가 분산된 콜로이드형 전 해질 설계를 통해 $t_{L i}$ 를 향상시킨 연구들의 경우, 1) 나 노입자 표면에 음이온과 강하게 결합할 수 있는 관능기 를 지니거나, ${ }^{39,41-43)}$ 2) 음이온과 화학적으로 결합한 형 태의 나노입자 사용의 경우로 나뉜다. 후자의 대표적 예 로, Cornell 대학의 Archer 교수 연구팀은 실리카 입 자 표면에 양이온을 띄는 관능기 1-methyl-1-propyl piperidinium (PP)을 도입함으로써 TFSI 음이온과 이 온결합을 통해 음이온의 mobility를 낮추고 공간 전하 의 균일성 확보를 통해 $t_{L i}+$ 의 상승을 유도하였다. ${ }^{44)}$ 본 연구에서는 $1 \mathrm{M}$ LiTFSI/Propylene Carbonate(PC) 전 해질에 $\mathrm{SiO}_{2}-\mathrm{PP}-\mathrm{TFSI}$ 가 분산된 Ionic liquid 전해질 을 사용하였으며, 나노입자의 농도 $48 \%$ 에서 최대 0.24 의 값을 도출했다. 이 수치는 기능성 실리카가 도입되 지 않은 바탕 전해질 (0.2)에 비해 향상된 수치임을 확 인하였다. 음이온 고정 역할을 하는 관능기의 모체로써 다양한 나노입자 $\left(\mathrm{SiO}_{2},{ }^{41-43,45-47)} \mathrm{ZrO}_{2}{ }^{48)}\right.$ Poly methyl methacrylate (PMMA), ${ }^{49)} \mathrm{Al}_{2} \mathrm{O}_{3}{ }^{45,50)} \mathrm{ZnO}^{51)}$ )가 사용 가능하다. 뿐만 아니라 Fig. 7과 같이, 여러 관능기가 도 입될 수 있는데, 소재와 관능기에 따라 저온 구동 안정

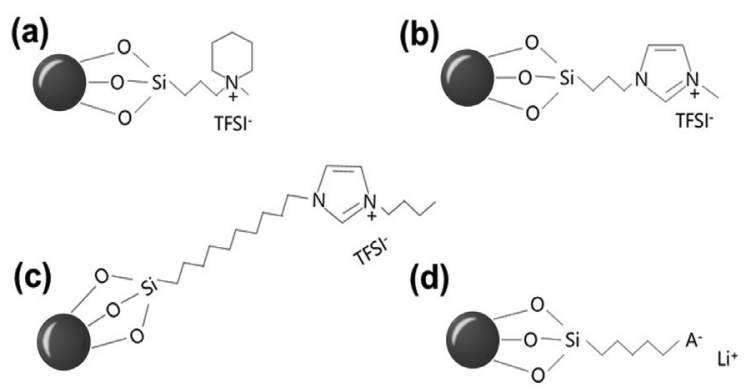

Fig. 7. 다양한 관능기가 도입된 나노입자들에 대한 모식도 ((a) Nanoparticles(NPS) - PP - TFSI, (b) NPs-lonic Liquid(IL)TFSI, (c) NPs-Ionic liquid-nanoscale ionic materials (IL-NIMs), (d) NPs-SO $\mathrm{Li}_{3}$

성 확보, ${ }^{49)}$ 표면 물성 강화 ${ }^{46)}$ 등의 추가적인 성능구현도 가능하기 때문에 목적에 맞는 적합한 소재 선정이 중요 하다.

이외에도 중국 우한대의 Huang 그룹이 사용한 Boron nitride 나노시트 (BNNS), ${ }^{33)}$ 미국 PNNL, 국내 연구진의 품드 실리카 기반의 콜로이드형 전해질 연구 사례 ${ }^{46)}$ 에서도 $t_{L i}{ }^{+}$향상 결과가 보고된 바가 있다. 특히, Urea를 활용한 합성법을 통해 $\mathrm{BNNS}$ 에 $\mathrm{NH}_{2}$ 관능기를 부여할 시 (Fig. 8a), 붕소원자의 산도를 향상시켜 음이 온의 mobility를 감소시켰다. 1 M LiTFSI in DOL(1,3Dioxolane)/DME(Dimethoxyethane) $+2 \mathrm{wt} \% \mathrm{LiNO}_{3}$ 에 해당 BNNS 입자를 $7.0 \mathrm{mg} \mathrm{mL}^{-1}$ 의 농도로 분산시킨 콜로이드형 전해질의 경우 0.55 의 $t_{L i}+$ 수치를 달성하였 으며, 이는 바탕 전해질 (0.47)보다 향상된 값이다 (Fig. $8 \mathrm{~b})$. 앞서 설명한 바와 같이 BNNS의 붕소원자는 음이 온 TFSI ${ }^{-}$의 N 원자와 Lewis Acid-Base 반응을 통해 음이온의 이동도 감소와 함께 $t_{L i}+$ 의 향상을 유도했으며, 이를 통해 전해질 내의 농도구배 완화에 따른 리튬 전착 시의 낮은 과전압과 전류밀도에 따른 용량 구현을 통해 우수한 율속특성을 확인하였다 (Fig. 8c). 이 밖에도 구 조적, 물리적으로 리튬 덴드라이트 억제에 유리한 구조 를 가졌기 때문에 금속 음극 안정화 물질로서의 역할도 가진다. 이외에도 나노물질 고유의 소재 특성을 통해 전 해질의 $t_{\mathrm{Li}+}$ 를 향상시킨 논문이 많으며, 콜로이드형 전해 질의 우수한 이온 전달 특성을 위해 소재 선정이 중요함 


\section{(a)}

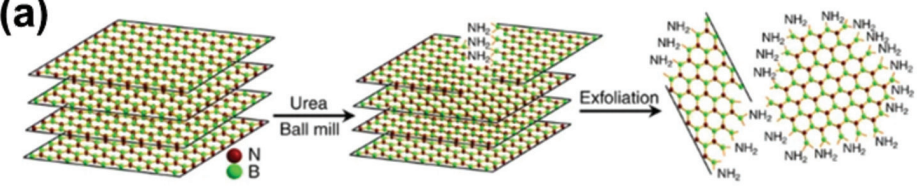

(b)

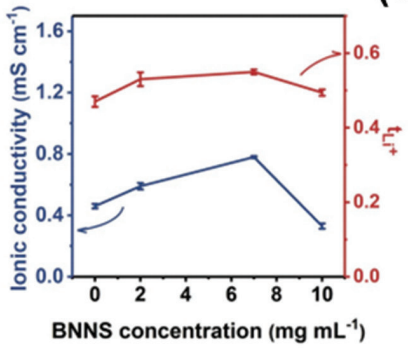

(c)

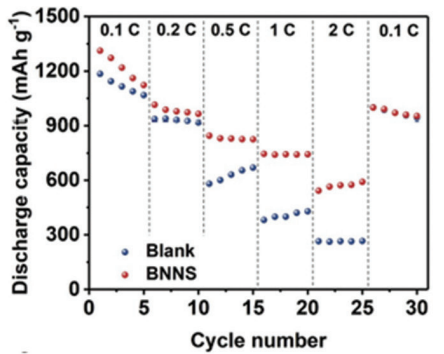

Fig. 8. (a) Urea를 통한 BN 박리와 관능기 형성. Reproduced from ref.34 with permission of Nature Publishing Group. (b) BNNS의 농 도에 따른 이온전도도 및 $\mathrm{t}_{\mathrm{Li}+}$ 변화 (7 mg mL${ }^{-1}$ 에서 최대값을 가짐), (c) Li-S 전지의 구동을 통해 측정한 율속에 따른 용량 구현. Reproduced from ref.33 with permission of Elsevier.

을 알 수 있다.

\section{5. 차셰대 리튬금속전지에서의 콜로이드형 전해질 기술}

\section{1. 금속이온의 균일 전착}

앞서 다룬 콜로이드형 전해질의 독특한 이온전달방 식 및 이를 통한 이온전도도, 이동도 향상은 차세대 전 지의 음극 소재로 재조명되고 있는 고용량 리튬금속의 계면 안정화에 유리하게 작용할 수 있다. 리튬금속음극 은 1970년대부터 개발되어 왔지만 충전 과정 중에 형성 되는 침상구조의 리튬 덴드라이트로 인해 오랫동안 상 용화 되지 못하고 있다. 리튬 덴드라이트는 분리막을 관 통하여 전지 내부단락을 발생시킬 수 있어 전지의 안전 성을 크게 위협하며, 전해질과의 부반응을 가속화하고, 계면을 퇴화시켜 극심한 전지열화를 유발한다. ${ }^{52,53)}$ 앞서 다룬 콜로이드형 전해질을 통한 향상된 리튬 이동도는 Sand time $(\tau)$ 식에 근거하여 리튬 덴드라이트 성장을 억제하는 파라미터로 여겨진다. ${ }^{54,55)}$

$$
\begin{gathered}
\tau=\pi D_{a p p} \frac{\left(Z_{\mathrm{c}} C_{0} F\right)^{2}}{4\left(J t_{\mathrm{a}}\right)^{2}} \\
t_{a} \approx 1-t_{L i^{+}}
\end{gathered}
$$

위 식에서 $D_{a p p}$ 는 겉보기 확산계수, $\mathrm{Z}_{c}$ 는 전하 수 $(\mathrm{Li}$
의 경우, 1$), F$ 는 패러데이 상수, $C_{0}$ 는 벌크 전해질에서 의 리튬 염의 농도, $J$ 는 전류밀도, $t_{a}$ 는 음이온 이동도를 의미한다. Sand time은 전극 계면에서 리튬이온의 농 도가 0이 되는데 걸리는 시간 즉, 전극 계면에서 덴드라 이트가 형성되는데까지 걸리는 시간을 의미하는 것으로 식을 참고하였을 때 음이온의 이동도가 작아지면, 즉 양 이온의 이동도가 커지면 Sand time이 길어지게 되고 이 는 리튬금속음극에서 덴드라이트 성장이 억제됨을 의미 한다.

미국 PNNL Xiao 박사의 Science ${ }^{56)}$ 보고에 따르면 전해질 상에서 이온종의 전달을 균일하고 신속하게 하 는 것이 리튬 덴드라이트의 억제에 중요한 변수임을 시 사했다 (Fig. 9a), 전극 표면에서 리튬이온의 전기화학 적 환원 반응이 매우 빠르다고 가정하였을 때, 리튬이온 의 전달 속도가 느린 경우에는 소모되는 리튬이온을 즉 각적으로 보상받지 못하기 때문에 리튬이온의 농도구배 가 가파르게된다. 그 경우, 더 많은 리튬이온을 받을 수 있는 형태로 리튬이 성장하게 되며 이에 따라 리튬 덴드 라이트가 형성되게 된다. 또한 이러한 리튬 덴드라이트 는 전류밀도 쏠림 현상을 겪게 되고 그 결과 성장이 가 속화된다 (Fig. 9b). 이와 반대로 리튬이온의 이동속도 가 균일하고, 빠른 경우에는 전극 표면에서의 농도구배 
(a)

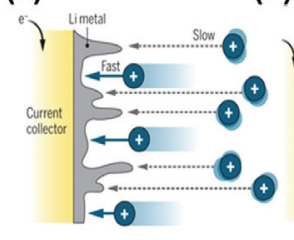

(b)

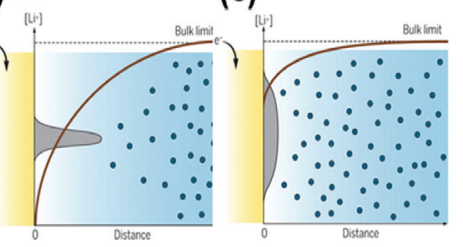

Fig. 9. 리튬이온의 전달현상과 전착 형상 모식도. (a) 불균일한 리 튬이온 전달과 이에 따른 전극 표면 형상 변화. (b) 극심한 이온 농도구배 형성으로 인한 리튬 덴드라이트 성장. (c) 완화된 이온 농도구배와 균일한 리튬 전착. Reproduced from ref.56 with permission of AAAS.

가 완화되고 리튬의 성장이 모든 방향으로 균일하게 이 루어진다 (Fig. 9c). 앞서 언급된 콜로이드형 전해질의 이온전도도 향상 및 리튬이온 이동수 $\left(t_{L i}{ }^{+}\right)$향상 효과는 리튬이온을 빠르고, 상대적으로 많이 전달할 수 있게 됨 을 의미하고, 이는 금속음극 표면에서 금속이온의 균일 한 전착을 유도한다.

리튬이온의 전달현상 완화를 통한 덴드라이트 억제 외 에도 나노입자의 전기화학적 특성에 따라 리튬 양이온과 의 공침효과를 통해 리튬의 균일한 전착을 유도 및 이를 통해 전극 계면을 제어하는 연구가 진행된 사례가 있다. 중국 칭화대 및 미국 Drexel 대 공동연구 그룹은 나노 다이아몬드가 분산된 콜로이드 전해질을 사용할 경우, 나노입자가 리튬이온과 동시에 전착됨으로써 덴드라이 트 성장을 억제할 수 있다고 보고하였다 (Fig. 10). ${ }^{57)}$ 일 차원리 전산모사를 통해 리튬이온이 낮은 자기 확산 계 수를 갖는 나노 다이아몬드 표면에 흡착되고, 이들의 공 동 전착과정을 통한 필름형 리튬 전착현상을 규명하였으 며 이를 실험적으로 구현하였다. 나노 다이아몬드의 주 요 역할은 4단계로 나누어진다 (Fig. 10a). (1) 리튬이온 이 구리 집전체에 비해 표면적이 넓고 상대적으로 높은 결합력을 갖는 나노 다이아몬드에 흡착된다. (2) 리튬이 온이 흡착된 나노다이아몬드가 대류와 전기적 이동에 의 해 구리 집전체 주변으로 이동한다. (3) 나노다이아몬드 가 초기 리튬 핵생성에 기여한다. (4) 나노다이아몬드의 작은 크기로 인해 결정 크기가 작은 리튬이 전착되고, 균일한 리튬 전착 형상을 갖게 된다. 나노 다이아몬드 기반의 콜로이드형 전해질을 통해서 리튬금속음극의 가

(a)

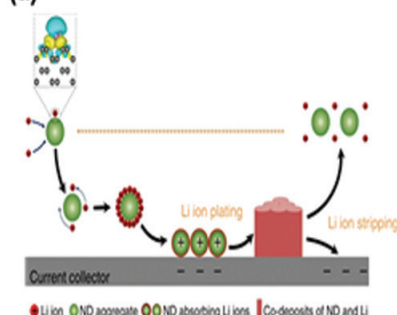

(b)

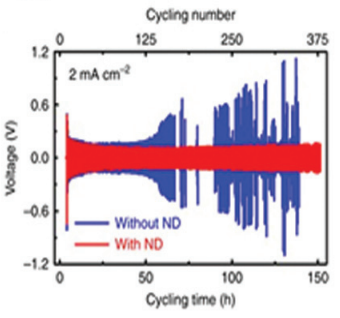

Fig. 10. (a) 전해질 내 나노다이아몬드의 덴드라이트 억제 메커니 즘에 대한 모식도. (b) Lil|Li 대칭 전지 사이클링 테스트 결 과 $\left(2 \mathrm{~mA} \mathrm{~cm}{ }^{-2}, 0.4 \mathrm{mAh} \mathrm{cm}{ }^{-2}\right)$. Reproduced from ref.57 with permission of Nature Publishing Group.

(a)

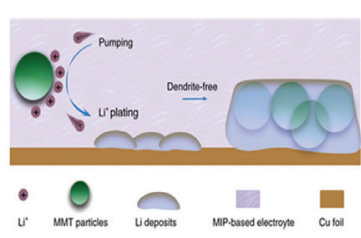

(b)

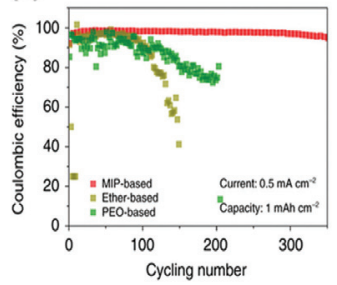

Fig. 11. (a) MMT 입자의 작용 메커니즘에 대한 모식도 (d) $\mathrm{Li}|| \mathrm{Cu}$ 전지 사이클링 테스트 결과 $\left(0.5 \mathrm{~mA} \mathrm{~cm} \mathrm{~cm}^{-2}, 1.0 \mathrm{mAh} \mathrm{cm}\right)^{-2}$ ) Reproduced from ref.58 with permission of Nature Publishing Group.

역성을 극적으로 향상시켰으며, $\mathrm{Li}|| \mathrm{Li}$ 대칭셀의 구동 에 있어 $2.0 \mathrm{~mA} \mathrm{~cm}$ 에서 최대 150 사이클 구동 가능성 을 입증하였다 (Fig. 10b). 하지만 덴드라이트 억제 가능 성을 구현하였음에도 불구하고 다른 나노입자에 비해 대 량생산이 어렵고 가격 경쟁력 측면에서도 불리하다는 문 제점이 해결되어야 할 것이다.

이 밖에도 중국 수저우 대학 연구팀은 리튬과 친화성 이 좋은 무기 나노입자를 활용하여 전극계면에서의 리 튬이온 고갈 현상을 억제하고, 이에 따라 균일한 리튬 전착이 유도된 연구결과를 발표하였다. ${ }^{58)}$ 전해질 내 분 산된 Montmorillonite (MMT)의 넓은 표면적과 흡착능 을 이용하여 나노입자 표면에서의 리튬이온 농도가 높 아지는 "Self-concentration" 현상을 이끌어냈으며, 이 를 이용하여 많은 양의 리튬이온 수송을 가능하게 하였 다 (Fig. 11a). 다량의 리튬이온 수송을 통해 전극 계면 에서의 이온 고갈시간 즉, Sand time을 지연시킴으로 
(a)
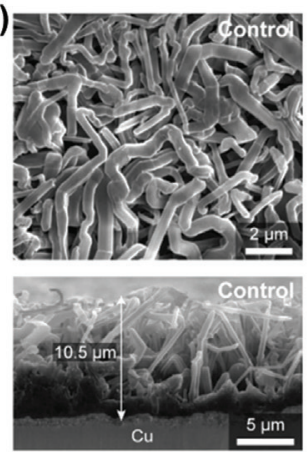

(d)

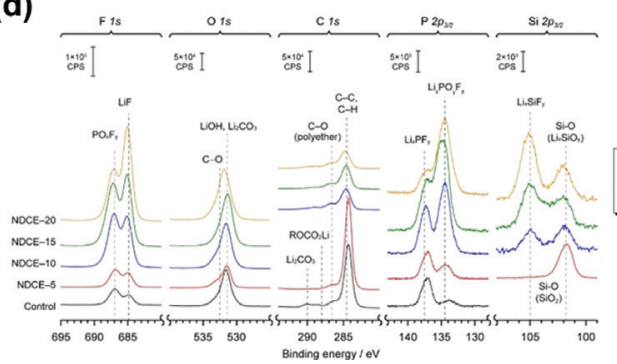

(b)
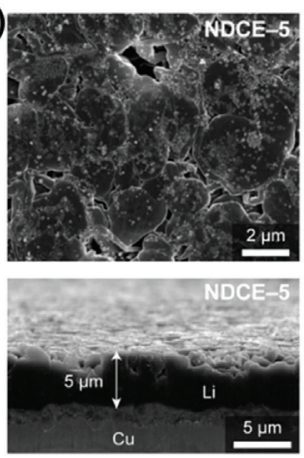

(c)
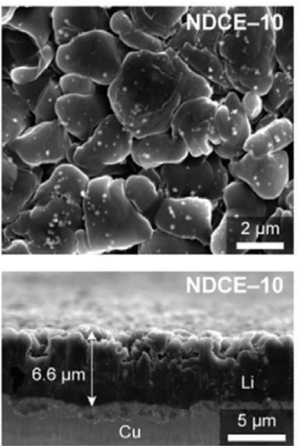

(e)

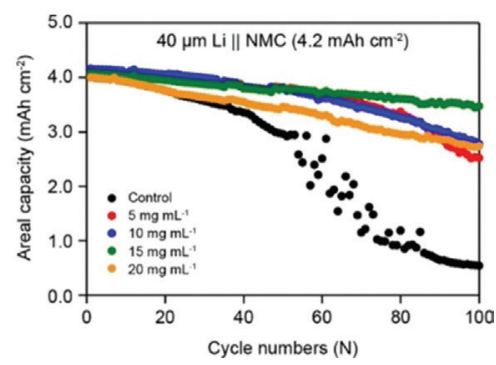

Fig. 12. SEM을 통한 리튬 전착 형상 분석 (a) 실리카 첨가 전, 바탕 전해질, (b) $5.0 \mathrm{mg} \mathrm{mL}^{-1}$ 실리카를 첨가한 콜로이형 전해질, (c) $10 \mathrm{mg}$ $\mathrm{mL}^{-1}$ 실리카를 첨가한 콜로이드형 전해질. 바탕 전해질 : $1 \mathrm{M} \mathrm{LiPF}_{6}$ in EC/Ethyl methyl Carbonate (EMC)(3/7, w/w) +2 wt\% Vinylene Carbonate (VC), (d) 고 해상도 XPS 분석을 통한 실리카 함량 별 SEl 성분 분석 결과, (e) 상용수준 전지 설계 기반에서 의 리튬금속전지 (Li||NMC811) 충 방전 사이클링 평가 결과 (충전 : 0.2, 방전 0.5 C-rate). Reproduced from ref.46 with permission of ACS Publication.

써 바탕 전해질에서의 불균일한 리튬이온 전착을 억제 하였다. 뿐만 아니라 MMT 입자는 낮은 자기 확산 계수 를 가지므로 입자 표면을 따라 리튬이 고르게 성장하는 것을 유도하게 된다. 실제로 전착된 리튬 형상을 통해 덴드라이트가 억제되었음을 확인할 수 있으며, $\mathrm{Li}|| \mathrm{Cu}$ 전지 테스트에서 통해 $0.5 \mathrm{~mA} \mathrm{~cm}{ }^{-2}, 1.0 \mathrm{mAh} \mathrm{cm}{ }^{-2}$ 조건에서 바탕 전해질에 비해 200 cycle $(150 \rightarrow 350$ cycle) 향상된 성능 보였다 (Fig. 11b). 리튬 음극면에서 의 높은 이온 흡착능과 낮은 이온 확산 장벽이 덴드라이 트 억제에 효과적인 것을 바탕으로 리튬 덴드라이트 억 제를 위한 나노소재 선정에 하나의 기준을 제시하였다.

\section{2. 계면의 기계적 강도 강화}

앞서 언급된 연구들을 비추어 보았을 때 전해질 내에 분산된 나노입자들은 전지 구동과정에서 전극 표면에 공침될 수 있으며, 나노입자의 특성에 따라 전해질과 전
극 계면 형성 반응에 지대한 영향을 미칠 수 있다. 실제 로 실리카의 경우, 이차전지 전해질 내 $\mathrm{LiPF}_{6}$ 염과 미량 의 수분으로 인한 $\mathrm{HF}$ 발생이 실리카 etching과 같은 화 학적 반응을 유도하여 계면 근처에서 hydrolysis 반응을 도모하고 이로 인해 반응 부생성물이 계면 성분으로 유 입될 수 있음이 확인되었다 (반응식 1-2). ${ }^{17,59)}$

$$
\begin{aligned}
& \mathrm{LiPF}_{6}+\mathrm{H}_{2} \mathrm{O} \rightarrow \mathrm{POF}_{3}+2 \mathrm{HF}+\mathrm{LiF} \downarrow \\
& \mathrm{SiO}_{2}+4 \mathrm{HF} \rightarrow \mathrm{SiF}_{4}+2 \mathrm{H}_{2} \mathrm{O}
\end{aligned}
$$

이러한 부반응의 발생은 리튬이온의 소모를 초래할 수 있으나, PNNL 및 국내 공동 연구진은 리튬금속음 극 표면에서 계면 성분 변화를 유도하여 리튬 덴드라이 트 억제 및 표면 안정화를 유도할 수 있다고 보고하였 다. ${ }^{46)}$ Fig. $12 \mathrm{a}-\mathrm{c}$ 와 같이 실리카를 분산시킨 나노 콜로 이드형 전해질 $(\mathrm{NDCE})$ 에서 5.0 및 $10 \mathrm{mg} \mathrm{mL}$ 농도로 실리카를 분산시킬 경우, 매우 효과적인 덴드라이트 성 장 억제효과를 구현할 수 있다. 실리카를 분산시킨 액체 


\section{특 집 ㅍ॥ 임민홍, 조영성, 이홍경}

(a)

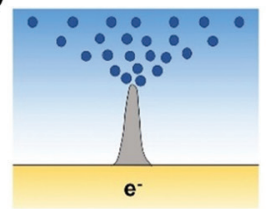

(b)

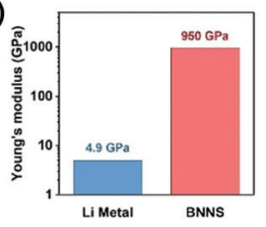

(h)

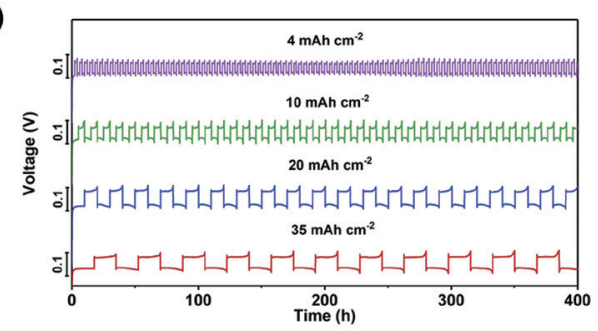

(d)

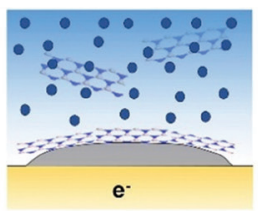

(c)

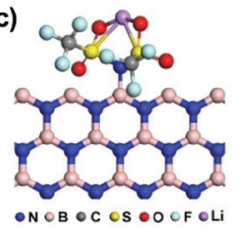

(f)
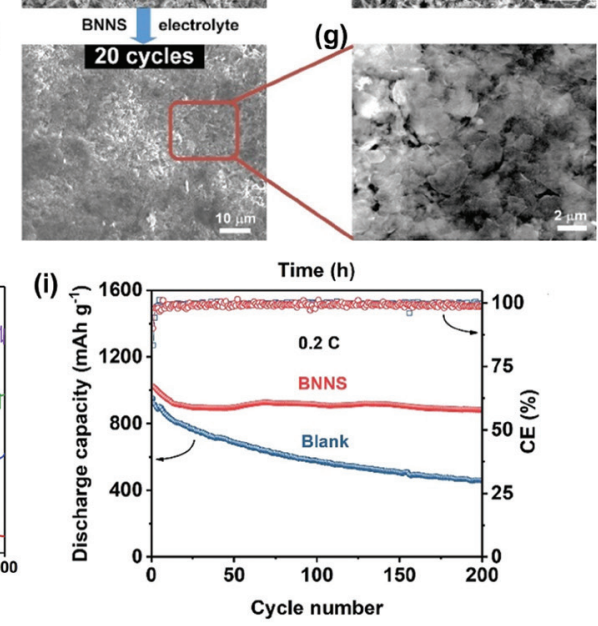

Fig. 13. (a) BNNS의 작용원리 및 효과 모식도. (b) 리튬금속과 BNNS의 Young's modulus, (c) Density functional theory (DFT) 계산을 통 한 BNNS와 LiTFSI 사이의 상용작용 분자 모델. 바탕 전해질에서의 LillCu 전지 Cu 전극 SEM 이미지 (d) 10 사이클, (e) 20 사이클 이후 $\left(1.0 \mathrm{~mA} \mathrm{~cm}{ }^{-2}, 1.0 \mathrm{mAh} \mathrm{cm}\right.$ ). (f), (g) BNNS를 추가한 전해질을 이용하여 추가 10 사이클 진행 이후의 Cu 전극 SEM 이미지 와 확대된 이미지. (h) Lil|Li 대칭 전지의 전착 용량 별 전압 vs 시간 그래프 (전류 밀도: $2.0 \mathrm{~mA} \mathrm{~cm}$ ). (i) Li-S 전지 테스트 결과 바탕 전해질: 1 M LiTFSI in DOL/DME (1/1, v/v) + (2 wt \% LiNO 3$)$. Reproduced from ref.33 with permission of Elsevier.

전해질을 리튬금속전지에 사용하였을 때 실리카의 계면 반응 참여가 리튬금속 표면에서 $\mathrm{LiF}$ 형성을 촉진시키 고, Fluorosilicate 와 같은 고강도성 세라믹 성분의 함 량을 증가시켜 리튬의 반응성을 제어할 수 있다고 보고 하였다 (Fig. $12 \mathrm{~d}$ ). 구체적인 반응식은 아래와 같다 (반 응식 3-4). 해당 전해질을 사용한 전지 내 전극과 전해 질 계면을 XPS로 분석한 결과 실리카 함량이 증가함 $>$ $10 \mathrm{mg} \mathrm{mL}{ }^{-1}$ )에 따라 $\mathrm{LiF}$ 와 $\mathrm{Li}_{\mathrm{x}} \mathrm{PO}_{\mathrm{y}} \mathrm{F}_{\mathrm{z}}$ 의 피크가 증가하 는 것이 확인되었으며, SEI 내 무기물 성분이 증가함에 따른 기계적 강도 향상 효과를 자아냈다. 이러한 효과를 바탕으로 $\mathrm{Li}\left(\mathrm{Ni}_{0.8} \mathrm{Mn}_{0.1} \mathrm{Co}_{0.1}\right) \mathrm{O}_{2}$ ( $\mathrm{NMC811)}$ 을 양극으로 사용한 상용수준의 리튬금속전지를 구동한 결과, 카보 네이트계 전해질에서 100 사이클까지 $85 \%$ 의 높은 용량 유지율을 기록하였다 (Fig. 12e).

$$
\begin{aligned}
& \mathrm{SiF}_{4}+2 \mathrm{LiF} \rightarrow \mathrm{Li}_{2} \mathrm{SiF}_{6} \downarrow \\
& \mathrm{Li}_{2} \mathrm{SiF}_{6}+8 \mathrm{LiOH} \\
& \rightarrow 6 \mathrm{LiF} \downarrow+\mathrm{Li}_{4} \mathrm{SiO}_{4} \downarrow+4 \mathrm{H}_{2} \mathrm{O}
\end{aligned}
$$

국내 UNIST 연구팀도 실리카와 알루미나 $\left(\mathrm{Al}_{2} \mathrm{O}_{3}\right)$ 를 사용한 콜로이드형 전해질을 비교 분석하여 나노입자의 계면 기계적 강도 향상에 있어 동일한 효과를 검증하였 다. ${ }^{45)}$ 리튬이온과 함께 침적된 나노입자가 물리적, 화학 적으로 계면 특성을 강화 시키는 것이 확인되었으며, 동 일 함량에서 실리카 기반의 콜로이드형 전해질을 사용 한 경우가 알루미나를 사용한 경우에 비해 우수한 전기 화학적 성능을 보임을 검증하였다. 이는 전지 내 존재 하는 미량의 $\mathrm{HF}$ 가 Silanol $(-\mathrm{Si}-\mathrm{OH})$ 작용기 사이의 Siloxane $(-\mathrm{Si}-\mathrm{O}-\mathrm{Si}-)$ 형성 반응의 촉매역할을 하 게 되고, ${ }^{60,61)}$ 이에 따라 형성된 실리카 나노입자 네트워 크의 효과 인 것으로 확인되었다. 이런 효과를 바탕으 로 실리카를 사용한 콜로이드형 전해질을 사용한 경우 $\mathrm{Li}|| \mathrm{Cu}$ 전지에서 사이클이 진행됨에도 최초에 형성된 최외각 SEI의 구조가 그대로 유지되는 것을 SEM을 통 해 확인하였다.

앞서 언급된 2차원 구조를 갖는 $\mathrm{BNNS}$ 를 액체 전해질 
에 분산시킨 콜로이드형 전해질을 리튬금속전지에 사용 한 경우 리튬금속 전착 형상을 완화시키는 효과를 보였 다 (Fig. 13a). ${ }^{33)}$ 함께 전착된 BNNS는 높은 기계적 강 도 (Young's modulus: $950 \mathrm{GPa}$ )를 바탕으로 전극 계 면의 물성을 강화하고 물리적 압력에 의한 리튬 음극의 부피 팽창 억제효과를 유도 할 수 있다 (Fig. 13b), 뿐 만 아니라, BNNS 내의 붕소와 TFSI 음이온의 질소 원 자 간의 상호작용은 4.2 에서 설명된 바와 같이 $\mathrm{t}_{\mathrm{Li}+}$ 향상 을 유도하여 리튬 덴드라이트 억제에 효과적이다 (Fig. 13c). 실제로 Fig. $13 \mathrm{~d}-\mathrm{g}$ 에서와 같이 전착된 리튬의 $\mathrm{SEM}$ 이미지를 통해, BNNS가 첨가되지 않은 전해질은 수지상의 리튬 전착이 확인되었으며, 불규칙적으로 분 포해 있음을 확인하였다. 반면, BNNS를 포함한 전해질 의 경우, 표면 형상이 매끄럽게 개선되는 것이 관찰되었 다. 이러한 특징들을 기반으로 고용량 $\left.(35 \mathrm{mAh} \mathrm{cm})^{-2}\right)$ $\mathrm{Li} \mid$ | Li 대칭 전지를 400 시간까지 안정적으로 구동시키 는데 성공하였으며 (Fig. 13h), Li-S 전지 내 전해질로 적용하여 우수한 용량 유지 특성을 구현하였다. (Fig. 13i)

\section{6. 결론 및 전망}

본 연구에서는 나노입자를 액체전해질에 분산시킨 나 노콜로이드형 전해질과 이의 물리화학적 구조 및 전기 화학적 특징들에 대해서 다루고, 해당 전해질을 활용하 여 리튬이차전지 및 차세대 리튬 전지의 성능을 향상시 킨 사례들에 대해서 알아보았다. 기존의 전해질을 구 성하는 염, 유기용매, 기타 첨가제를 통한 전해질 설계 와는 달리 고체상의 기능성 나노입자를 분산시킴으로 써 전해질 본연의 특성에서 벗어나 이온전달모드를 바 꿔 이온전도도 및 리튬이온 이동수를 향상시킬 수 있으 며, 전지 내 계면반응에 물리적/화학적으로 일부 관여하 여 전극/전해질 계면 구조 및 물성을 개질시킬 수 있다 는 점에서 향후 리튬이온전지에 요구되는 고성능 및 고 안전성 확보에 유리할 수 있다.

나노콜로이드형 전해질의 유연한 전해질 설계 및 추 가 기능성 부여 가능성을 토대로 최근 차세대 전지로 각
광받고 있는 리튬금속전지의 리튬 음극의 가역성 확보 와 안전성 향상을 도모 할 수 있다. 리튬금속의 경우, 덴 드라이트 억제가 리튬금속전지의 상용화에 있어 매우 중요한 요소이기 때문에 기존의 액체 전해질으로는 한 계가 있다는 점을 감안할 때, 나노콜로이드형 전해질의 설계를 기반으로 최적의 용매 염 조성과 나노입자의 효 율적인 설계, 조성 최적화를 통해서 리튬 이동수의 향 상과 이를 통한 덴드라이트 성장 지연을 할 수 있고, 다 차원 형태의 유/무기 나노입자는 리튬 전착시 공침과정 을 통해서 직접적으로 계면 반응 참가하거나 입자 자체 가 계면을 구성하는 성분으로 작용하게 되어 리튬/전해 질 계면의 기계적, 화학적 안정성 강화를 도모할 수 있 을 것으로 기대된다.

그럼에도 불구하고, 나노 콜로이드형 전해질의 한계 점으로써 나노입자 분산성 유지와 첨가량에 따른 전해 질 점도 증가, 전해질 가격 상승 여부 등 해결해야 할 문 제점들이 존재하기 때문에 본 논문에서 다룬 나노콜로 이드형 전해질의 주요 특성 및 원리를 기반으로 개발한 최신 나노 기술과 섬세한 입자표면 제어기술이 접목된 스마트 나노입자를 활용한 현 문제점 해결과 동시에 향 후 리튬이차전지의 성능 및 안전성을 획기적으로 향상 시키는 것 등의 발전이 기대된다. 이차전지 보급화에 따 른 중대형 전지의 안전성이 중요한 시점에서 전해질의 난연 특성을 부여할 수 있는 기능성 나노입자 기술이 도 입된다면 이차전지의 발화를 억제할 수 있는 기술로 발 전할 수 있을 것으로 전망한다. 또한, 콜로이드형 전해 질 내 나노입자의 이온종과 상호작용하는 특수거동에 대한 이해를 기반으로 리튬이차전지 내부 분석 기술에 응용될 가능성도 농후하다. 특히, 형광특성이 부여된 나 노입자를 분산시킨 콜로이드형 전해질과 현미경을 접목 하여 리튬과 음이온 그리고 용매간의 용매화 구조를 이 해하고 이온 전달현상에 대한 시각 정보를 제공할 수 있 을 것으로 기대한다. 기존에 나노물질을 전극에 도입하 여 고정된 위치에서 기능성을 발현한 것과는 달리 액상 에서 운동성을 갖게됨으로써 발현할 수 있는 기능은 상 이하고 다양할 수 있다는 점을 감안 할 때, 바이오 및 의 학 등 다양한 응용으로써 활용된 나노기술의 융복합 연 
구를 통해 향후 콜로이드형 전해질의 새로운 가능성과 이차전지 기술의 혁신을 기대해본다.

\section{Acknowledgment}

This research was supported by the Basic Science Research Program through the National Research Foundation (NRF) of Korea funded by the Ministry of Science, ICT (NRF-2020R1C1C1009159)

\section{REFERNCES}

1. J. G. Park, "Material Technology of Nano powder(in Korean), "Ceramist 10 [1], 15-27 (2007).

2. S. K. Kang, H. N. Han, S. U. Kim and I. S. Choi, "Research on mechanical properties of nano material (in Korean) ," Ceramist 19 [1], 45-54 (2016).

3. S. H. Oh, M. Legros, D. Kiener and G. Dehm, "In situ observation of dislocation nucleation and escape in a submicrometre aluminium single crystal," Nat. Mater. 8 [2], 95-100 (2009).

4. D. Guo, G. Xie and J. Luo, "Mechanical properties of nanoparticles: basics and applications," J. Phys. D: Appl. Phys. 47 [1], 013001 (2013).

5. Q. Zhang, E. Uchaker, S. L. Candelaria and G. Cao, "Nanomaterials for energy conversion and storage," Chem. Soc. Rev. 42 [7], 3127-3171 (2013).

6. M. M. Khin, A. S. Nair, V. J. Babu, R. Murugan and S. Ramakrishna, "A review on nanomaterials for environmental remediation," Energy Environ. Sci. 5 [8], 8075-8109 (2012).

7. O. V. Salata, "Applications of nanoparticles in biology and medicine," J. Nanobiotechnology 2 [1], 3 (2004).

8. C.-M. Horejs, "I, nanorobot," Nat. Phys. 16 [3], 239239 (2020).

9. I. Khan, K. Saeed and I. Khan, "Nanoparticles: Properties, applications and toxicities," Arab. J. Chem. 12 [7], 908-931 (2019).

10. P. G. Bruce, B. Scrosati and J.-M. Tarascon, "Nanomaterials for Rechargeable Lithium Batteries," Angew. Chem. Int. 47 [16], 2930-2946 (2008).
11. D. Fu, B. Luan, S. Argue, M. N. Bureau and I. J. Davidson, "Nano $\mathrm{SiO} 2$ particle formation and deposition on polypropylene separators for lithiumion batteries," J. Power Sources 206, 325-333 (2012).

12. J.-A. Choi, S. H. Kim and D.-W. Kim, "Enhancement of thermal stability and cycling performance in lithium-ion cells through the use of ceramic-coated separators," J. Power Sources 195 [18], 6192-6196 (2010).

13. M. S. Whittingham, "Lithium Batteries and Cathode Materials," Chem. Rev. 104 [10], 4271-4302 (2004).

14. A. Yamada, S. C. Chung and K. Hinokuma, "Optimized LiFePO for Lithium Battery Cathodes," J. Electrochem. Soc. 148 [3], A224 (2001).

15. K. T. Lee and J. Cho, "Roles of nanosize in lithium reactive nanomaterials for lithium ion batteries," Nano Today 6 [1], 28-41 (2011).

16. J. Wang and X. Sun, "Understanding and recent development of carbon coating on $\mathrm{LiFePO} 4$ cathode materials for lithium-ion batteries," Energy Environ. Sci. 5 [1], 5163-5185 (2012).

17. C. K. Chan, H. Peng, G. Liu, K. McIlwrath, X. F. Zhang, R. A. Huggins and Y. Cui, "High-performance lithium battery anodes using silicon nanowires," Nat. Nanotechnol. 3 [1], $31-5$ (2008).

18. C. Yang, D. J. Lee, H. Kim, K. Kim, J. Joo, W. B. Kim, Y. B. Song, Y. S. Jung and J. Park, "Synthesis of nano-sized urchin-shaped LiFePO4 for lithium ion batteries," RSC Advances 9 [24], 13714-13721 (2019).

19. H.-S. Jeong, D.-W. Kim, Y. U. Jeong and S.-Y. Lee, "Effect of phase inversion on microporous structure development of Al2O3/poly(vinylidene fluoridehexafluoropropylene)-based ceramic composite separators for lithium-ion batteries," J. Power Sources 195 [18], 6116-6121 (2010).

20. H.-S. Jeong, S. C. Hong and S.-Y. Lee, "Effect of microporous structure on thermal shrinkage and electrochemical performance of $\mathrm{Al2O} 3$ / poly(vinylidene fluoride-hexafluoropropylene) composite separators for lithium-ion batteries," J. Membr. Sci. 364 [1], 177-182 (2010).

21. B. J. Landi, M. J. Ganter, C. D. Cress, R. A. DiLeo and R. P. Raffaelle, "Carbon nanotubes for lithium ion batteries," Energy Environ. Sci. 2 [6], 638-654 (2009). 
22. X.-L. Wu, Y.-G. Guo, J. Su, J.-W. Xiong, Y.-L. Zhang and L.-J. Wan, "Carbon-Nanotube-Decorated Nano-LiFePO4@C Cathode Material with Superior High-Rate and Low-Temperature Performances for Lithium-Ion Batteries," Adv. Energy Mater. 3 [9], 1155-1160 (2013).

23. S. Luo, K. Wang, J. Wang, K. Jiang, Q. Li and S. Fan, "Binder-Free LiCoO2/Carbon Nanotube Cathodes for High-Performance Lithium Ion Batteries," Adv. Mater. 24 [17], 2294-2298 (2012).

24. H. Gao, X. Zeng, Y. Hu, V. Tileli, L. Li, Y. Ren, X. Meng, F. Maglia, P. Lamp, S.-J. Kim, K. Amine and Z. Chen, "Modifying the Surface of a High-Voltage Lithium-Ion Cathode," ACS Appl. Energy Mater. 1 [5], 2254-2260 (2018).

25. Y. Li, X. Liu, D. Ren, H. Hsu, G.-L. Xu, J. Hou, L. Wang, X. Feng, L. Lu, W. Xu, Y. Ren, R. Li, X. He, $\mathrm{K}$. Amine and M. Ouyang, "Toward a high-voltage fast-charging pouch cell with $\mathrm{TiO} 2$ cathode coating and enhanced battery safety," Nano Energy 71, 104643 (2020).

26. C. W. Lin, C. L. Hung, M. Venkateswarlu and B. J. Hwang, "Influence of $\mathrm{TiO} 2$ nano-particles on the transport properties of composite polymer electrolyte for lithium-ion batteries," J. Power Sources 146 [1], 397-401 (2005).

27. W. Liu, S. W. Lee, D. Lin, F. Shi, S. Wang, A. D. Sendek and Y. Cui, "Enhancing ionic conductivity in composite polymer electrolytes with well-aligned ceramic nanowires," Nat. Energy 2 [5], 17035 (2017).

28. Y. Liu, D. Lin, P. Y. Yuen, K. Liu, J. Xie, R. H. Dauskardt and Y. Cui, "An Artificial Solid Electrolyte Interphase with High Li-Ion Conductivity, Mechanical Strength, and Flexibility for Stable Lithium Metal Anodes," Adv. Mater. 29 [10], 1605531 (2017).

29. R. Xu, X.-Q. Zhang, X.-B. Cheng, H.-J. Peng, C.-Z. Zhao, C. Yan and J.-Q. Huang, “Artificial Soft-Rigid Protective Layer for Dendrite-Free Lithium Metal Anode," Adv. Funct. Mater. 28 [8], 1705838 (2018).

30. Y. Zhao, Z. Huang, S. Chen, B. Chen, J. Yang, Q. Zhang, F. Ding, Y. Chen and X. Xu, "A promising PEO/LAGP hybrid electrolyte prepared by a simple method for all-solid-state lithium batteries," Solid State Ion. 295, 65-71 (2016).

31. W. Zhang, J. Nie, F. Li, Z. L. Wang and C. Sun, "A durable and safe solid-state lithium battery with a hybrid electrolyte membrane," Nano Energy 45, 413 419 (2018).

32. C. Pfaffenhuber, M. Göbel, J. Popovic and J. Maier, "Soggy-sand electrolytes: status and perspectives," Phys. Chem. Chem. Phys. 15 [42], 18318-18335 (2013).

33. J. Wu, X. Li, Z. Rao, X. Xu, Z. Cheng, Y. Liao, L. Yuan, X. Xie, Z. Li and Y. Huang, "Electrolyte with boron nitride nanosheets as leveling agent towards dendrite-free lithium metal anodes," Nano Energy 72, 104725 (2020).

34. W. Lei, V. N. Mochalin, D. Liu, S. Qin, Y. Gogotsi and Y. Chen, "Boron nitride colloidal solutions, ultralight aerogels and freestanding membranes through onestep exfoliation and functionalization," Nat. Commun 6 [1], 8849 (2015).

35. S. K. Das and A. J. Bhattacharyya, "Influence of Oxide Particle Network Morphology on Ion Solvation and Transport in "Soggy Sand" Electrolytes," J. Phys. Chem. B 114 [20], 6830-6835 (2010).

36. N. Kaskhedikar, Y. Karatas, G. Cui, J. Maier and H. D. Wiemhöfer, "Nanocomposites based on borate esters as improved lithium-ion electrolytes," J. Mater. Chem. 21 [32], 11838-11843 (2011).

37. A. Jarosik, C. Pfaffenhuber, A. Bunde and J. Maier, "Electrochemical Investigations of Polyethylene Glycol-Based "Soggy Sand" Electrolytes - From the Local Mechanism to the Overall Conduction," Adv. Funct. Mater. 21 [20], 3961-3966 (2011).

38. A. J. Bhattacharyya, "Ion Transport in Liquid Salt Solutions with Oxide Dispersions: "Soggy Sand" Electrolytes," J. Phys. Chem. Lett. 3 [6], 744-750 (2012).

39. A. J. Bhattacharyya, M. Dollé and J. Maier, "Improved Li-Battery Electrolytes by Heterogeneous Doping of Nonaqueous Li-Salt Solutions," Electrochem. SolidState Lett. 7 [11], A432 (2004).

40. L. Shen, H. B. Wu, F. Liu, J. Shen, R. Mo, G. Chen, G. Tan, J. Chen, X. Kong, X. Lu, Y. Peng, J. Zhu, G. Wang and Y. Lu, "Particulate Anion Sorbents as Electrolyte Additives for Lithium Batteries," Adv. Funct. Mater. 30 [49], 2003055 (2020).

41. J. L. Schaefer, S. S. Moganty, D. A. Yanga and L. A. Archer, "Nanoporous hybrid electrolytes," J. Mater. Chem. 21 [27], 10094-10101 (2011).

42. Y. Lu, S. K. Das, S. S. Moganty and L. A. Archer, 
"Ionic Liquid-Nanoparticle Hybrid Electrolytes and their Application in Secondary Lithium-Metal Batteries," Adv. Mater. 24 [32], 4430-4435 (2012).

43. S. Choudhury, A. Agrawal, S. Wei, E. Jeng and L. A. Archer, "Hybrid Hairy Nanoparticle Electrolytes Stabilizing Lithium Metal Batteries," Chem. Mater. 28 [7], 2147-2157 (2016).

44. K. S. Korf, Y. Lu, Y. Kambe and L. A. Archer, "Piperidinium tethered nanoparticle-hybrid electrolyte for lithium metal batteries," J. Mater. Chem. A 2 [30], 11866-11873 (2014).

45. M. Kim, Y. Jeon, Y.-G. Cho and H.-K. Song, "Nanobead-reinforced outmost shell of solidelectrolyte interphase layers for suppressing dendritic growth of lithium metal," J. Power Sources 414, 218224 (2019).

46. J. Lee, H.-S. Lim, X. Cao, X. Ren, W.-J. Kwak, I. A. Rodríguez-Pérez, J.-G. Zhang, H. Lee and H.-T. Kim, "Lithium Dendrite Suppression with a Silica Nanoparticle-Dispersed Colloidal Electrolyte," ACS Appl. Mater. Interfaces 12 [33], 37188-37196 (2020).

47. J. L. Schaefer, D. A. Yanga and L. A. Archer, "High Lithium Transference Number Electrolytes via Creation of 3-Dimensional, Charged, Nanoporous Networks from Dense Functionalized Nanoparticle Composites," Chem. Mater. 25 [6], 834-839 (2013).

48. S. S. Moganty, N. Jayaprakash, J. L. Nugent, J. Shen and L. A. Archer, "Ionic-Liquid-Tethered Nanoparticles: Hybrid Electrolytes," Angew. Chem. Int. 49 [48], 9158-9161 (2010).

49. Y. Li, K. W. Wong, Q. Dou, W. Zhang and K. M. Ng, "Improvement of Lithium-Ion Battery Performance at Low Temperature by Adopting Ionic LiquidDecorated PMMA Nanoparticles as Electrolyte Component," ACS Appl. Energy Mater. 1 [6], 26642670 (2018).

50. H. Xu, Y. He, Z. Zhang, J. Shi, P. Liu, Z. Tian, K. Luo, X. Zhang, S. Liang and Z. Liu, "Slurry-like hybrid electrolyte with high lithium-ion transference number for dendrite-free lithium metal anode," J. Energy Chem. 48, 375-382 (2020).

51. D.-P. Liu, G.-D. Li, Y. Su and J.-S. Chen, "Highly Luminescent $\mathrm{ZnO}$ Nanocrystals Stabilized by IonicLiquid Components," Angew. Chem. Int. 45 [44], 7370-7373 (2006).

52. X.-B. Cheng, R. Zhang, C.-Z. Zhao and Q. Zhang,
"Toward Safe Lithium Metal Anode in Rechargeable Batteries: A Review," Chem. Rev. 117 [15], 10403 10473 (2017).

53. J. M. Tarascon and M. Armand, "Issues and challenges facing rechargeable lithium batteries," Nature 414 [6861], 359-367 (2001).

54. H. J. S. Sand, "III. On the concentration at the electrodes in a solution, with special reference to the liberation of hydrogen by electrolysis of a mixture of copper sulphate and sulphuric acid," Lond.Edinb. Dubl.Phil.Mag. 1 [1], 45-79 (1901).

55. P. Bai, J. Li, F. R. Brushett and M. Z. Bazant, "Transition of lithium growth mechanisms in liquid electrolytes,” Energy Environ. Sci. 9 [10], 3221-3229 (2016).

56. J. Xiao, "How lithium dendrites form in liquid batteries," Science 366 [6464], 426 (2019).

57. X.-B. Cheng, M.-Q. Zhao, C. Chen, A. Pentecost, K. Maleski, T. Mathis, X.-Q. Zhang, Q. Zhang, J. Jiang and Y. Gogotsi, "Nanodiamonds suppress the growth of lithium dendrites," Nat. Commun 8 [1], 336 (2017).

58. W. Chen, Y. Hu, W. Lv, T. Lei, X. Wang, Z. Li, M. Zhang, J. Huang, X. Du, Y. Yan, W. He, C. Liu, M. Liao, W. Zhang, J. Xiong and C. Yan, "Lithiophilic montmorillonite serves as lithium ion reservoir to facilitate uniform lithium deposition," Nat. Commun 10 [1], 4973 (2019).

59. D. V. Novikov, E. Y. Evschik, V. I. Berestenko, T. V. Yaroslavtseva, A. V. Levchenko, M. V. Kuznetsov, N. G. Bukun, O. V. Bushkova and Y. A. Dobrovolsky, "Electrochemical performance and surface chemistry of nanoparticle Si@SiO2 Li-ion battery anode in LiPF6-based electrolyte," Electrochim. Acta 208, 109-119 (2016).

60. C. J. Brinker and G. W. Scherer, CHAPTER 3 Hydrolysis and Condensation II: Silicates. In Sol-Gel Science, Brinker, C. J.; Scherer, G. W., Eds. Academic Press: San Diego, 1990; pp 96-233.

61. R. Winter, J. B. Chan, R. Frattini and J. Jonas, "The effect of fluoride on the sol-gel process," J. NonCryst. Solids 105 [3], 214-222 (1988).

62. B. Kumar and S. J. Rodrigues, "Ionic conductivity of colloidal electrolytes," Solid State Ion. 167 [1], 91-97 (2004).

63. C. Pfaffenhuber and J. Maier, "Quantitative estimate of the conductivity of a soggy sand electrolyte: 
example of (LiClO4, THF):SiO2," Phys. Chem. Chem. Phys. 15 [6], 2050-2054 (2013).

64. A. J. Bhattacharyya and J. Maier, "Second Phase
Effects on the Conductivity of Non-Aqueous Salt Solutions: "Soggy Sand Electrolytes"," Adv. Mater. 16 [9-10], 811-814 (2004).
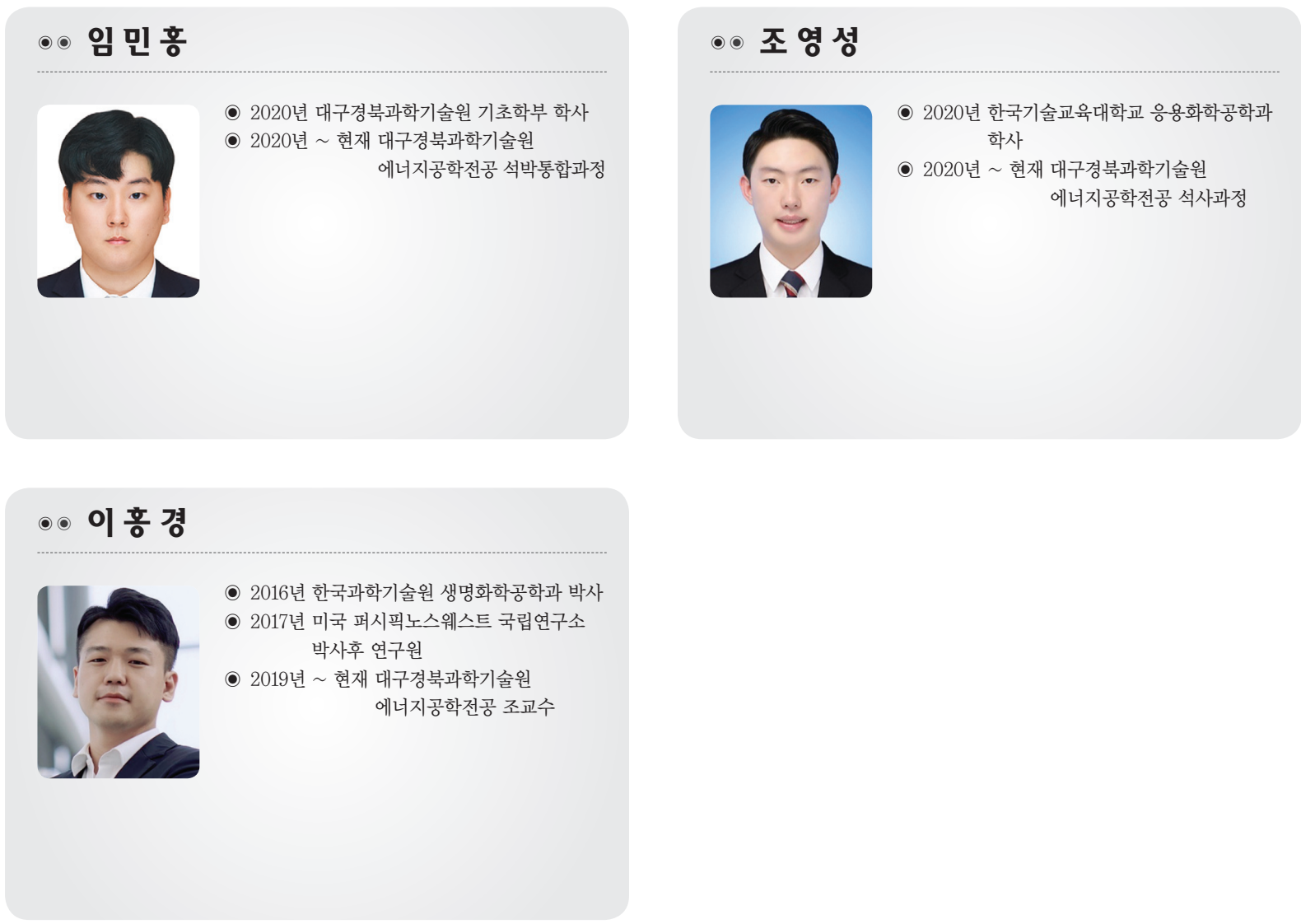